J une 12, 2008
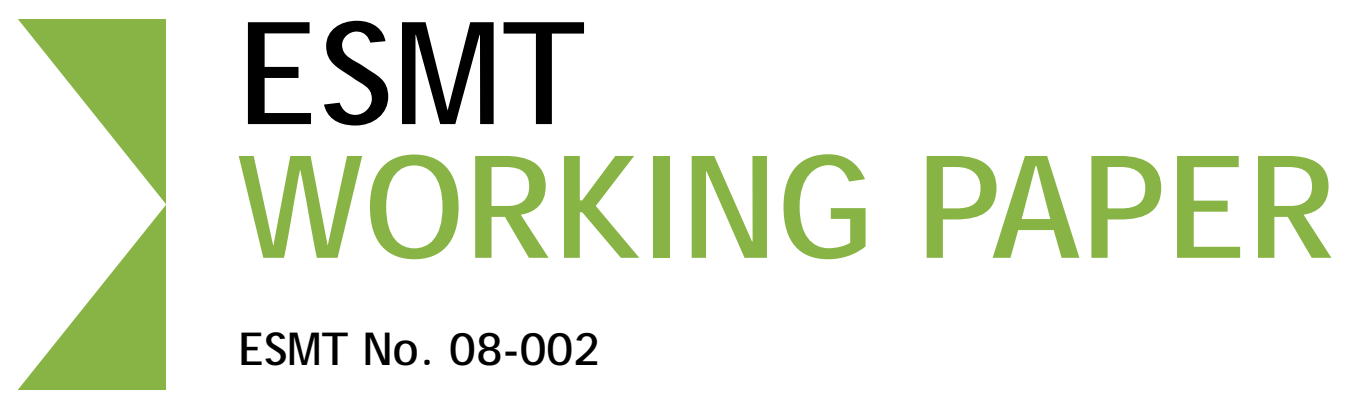

ESMT No. 08-002

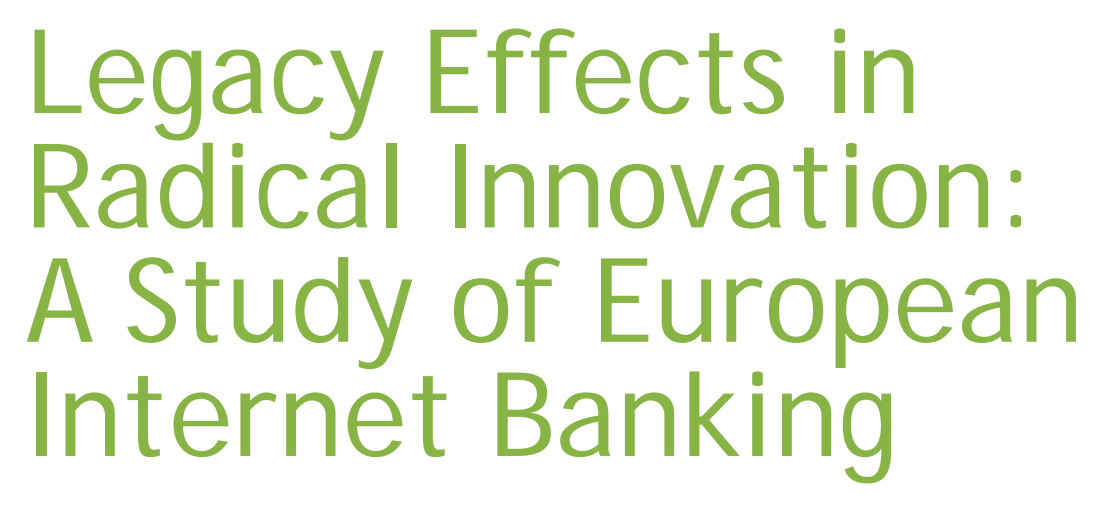

Erik H. Schlie, ESMT

J aideep C. Prabhu, Tanaka Business School, Imperial College London Rajesh K. Chandy, Carlson School of Management, University of Minnesota 


\title{
Abstract
}

\section{Legacy Effects in Radical Innovation: A Study of European Internet Banking}

\author{
Author(s): Erik H. Schlie, ESMT \\ J aideep C. Prabhu, Tanaka Business School, Imperial College London \\ Rajesh K. Chandy, Carlson School of Management, \\ University of Minnesota
}

\begin{abstract}
How do firms cope with the challenges of disruptive change in their industry? Numerous studies have highlighted that success with any prior technology creates a negative legacy effect for the next radical technological shift. We question the overly pessimistic view of such legacy effects and ask how quickly firms embrace technological breakthroughs by radically innovating and who wins in the longer term? In this paper, we argue that legacy is a multi-faceted construct whose diverse aspects could simultaneously have different effects on innovation speed and market performance. We identify three main types of legacy related to technology, organizational, and country-level influences. Previous research tends to focus on technological or market effects in isolation, whereas we seek to study the effects of both firm and country legacy simultaneously on speed to radical innovation and market performance over time. Based on a conceptual framework we develop six hypotheses concerning the legacy effects on initial speed radical innovation and subsequent market performance. We chose the European retail banking industry and the focal innovation of transactional Internet banking as a suitable empirical context to employ quantitative hypothesis testing. Detailed and longitudinal (1996-2001) data were collected for a sample of 123 banks from six European countries: United Kingdom, Germany, France, Sweden, Finland, and Denmark. We specified a model and used threestage least squares (3SLS) as a method to estimate simultaneous regression equations due to endogeneity of a key variable. We show that the prevailing negative view of legacies is likely to be overstated.
\end{abstract}

Keywords: innovation, legacy, internet banking, europe.

JEL Classification: M31 


\section{Introduction}

Creative destruction is a fundamental aspect of capitalism (Schumpeter 1934, 1950). In most industries, cycles of technological change cause new product generations to emerge, grow and disappear again, leading to the rise and fall of firms that compete to embrace this change (Foster 1986; Utterback 1994). Over the last century, the typewriter industry experienced four successive waves of such technological transformation: from manual to electric typewriters to word processors to personal computers, each wave leading to changes in the fortunes of the firms involved (Utterback 1994). More recently, the hard disk drive industry witnessed six successive waves of technology change over a 20-year period, all of which resulted in the destruction of the previous generation of products (Christensen 1993, 1997). Moreover, in both these examples, as well as others (e.g., Henderson and Clark 1990; Henderson 1993), no firm that led in one generation also became the leading firm in the following generation. Thus, existing evidence suggests that a firm's success with any one technology creates a negative legacy for the next new technology, and so on.

Why are legacy effects negative? The existing literature suggests several underlying reasons related to expertise with technologies and consumer markets. First, learning how to employ prior-generation technologies creates lasting firm-specific technological capabilities. However, this embedded know-how may eventually become obsolete or "competencedestroying" after the next technological shift (Abernathy and Clark 1985; Anderson and Tushman 1990). Second, learning to engage with existing customers also creates lasting firmspecific capabilities or organizational routines (cf. Nelson and Winter 1982). As a result, market expertise based on existing customer needs may not be readily transferable to other customer segments, thus causing firms to overlook the next radical transformations in their industries (Christensen 1997). Furthermore, leading incumbents tend to lag in radical innovation because their current market access to a large customer base reduces the incentives to embrace the subsequent generation of know-how (Ghemawat 1991). Third, negative legacies occur because companies face dual challenges of playing two strategic games at once with limited resources: they could focus on the current technology by protecting their existing investments and assuming the role of effective defenders. Alternatively, they could also participate in multiple related technologies and thus dividing their commitments with limited resources and try to become effective attackers (Foster 1986). Yet, few companies successfully master such dual challenges, thus frequently leading to inferior incumbent performance (Cooper and Schendel 1976). Fourth, incumbent managers, despite being one-time innovators, tend to be risk-averse and "conservationist" when faced with further radical innovations 
(Utterback 1994). In particular, managers fall into this trap when current technologies and their incremental extensions are still highly profitable and when satisfying current customer needs drives the allocation of firm resources and internal reward systems (Christensen and Bower 1996).

Must all legacy effects always be negative? Despite the compelling evidence and arguments mentioned above, it is possible that the current pessimistic view is at least partly due to some important limitations of existing research. First, existing research has a somewhat limited view of the types of legacies that exist. Legacies at the firm-level are likely to relate to technological capabilities (e.g., banks' direct banking know-how prior to adopting Internet banking) and organizational factors (e.g., market incumbency), while controlling for resource endowments (e.g., financial strength, physical size). Yet, existing research tends to focus on either one of these generic elements but not both, and without adopting a more comprehensive approach in a single framework. For example, existing studies have concentrated on the role of technological experience and capabilities (e.g., King and Tucci 2000, 2002; Chandrashekaran et al. 1999), on the role of incumbency (e.g., Chandy and Tellis 2000; Hill and Rothaermel 2003), and on the role of resources, such as specific assets (e.g., Tripsas 1997). Moreover, because firms operate within different national settings, country-level institutional and contextual legacy effects are also likely to exist (e.g., different market sizes and industry concentrations as well as technological infrastructure). Again, such country-level legacies tend to be ignored in most existing research. Second, past research has typically not examined the effects of different types of legacies over time, i.e., research has rarely separated effects in the early stages of the new technology from what happens as the technology matures. Nevertheless, certain legacies may have initially harmful effects on firms' ability to innovate, which are overturned at a later stage. Third, and related: existing research has typically examined success with the new technology on a subset of a range of possible aspects of performance. Thus, while some research has focused on the speed with which firms adopt the new technology (e.g., Kessler and Chakrabarti 1999; Schoenecker and Cooper 1998), other research has examined the market performance, i.e., market share or sales (e.g., Hill and Rothaermel 2003), few studies have looked at both speed and market performance (e.g. Gopalakrishnan 2000; Isobe et al. 2000). For a more complete understanding of legacy effects, therefore, it would be necessary to examine how legacy effects play out over time, as the new technology is adopted throughout an industry and as firms of different types - entrants and incumbents - learn to embrace the new technology and use it to develop and commercialize radical innovations.

In this paper, we challenge the existing, pessimistic view of legacy effects and argue that certain legacies can actually work to the advantage of incumbent firms and that legacies can 
have different short versus long-term effects. To do so, we first expand the notion of legacies to three main types of legacy effects: technology, organizational, and country-level legacies. We examine the effects of these types of legacy in the empirical context of industry that has faced the recent challenge of a radical technology shift: transactional Internet banking. With the potential to revolutionize the retail banking model, the focal innovation is suitably embedded in prior technology legacies (telephone and PC banking) and subsequent innovation efforts (mobile banking, TV banking). In order to test our hypotheses we collected longitudinal data for a sample of 123 European retail banks and use three-stage least squares (3SLS) to estimate simultaneous regression models explaining speed to innovation and market performance. Furthermore, we study the industry-wide evolution of Internet banking from inception to maturity, and examine firms' performance over time on both speed of innovation as well as eventual market performance. Specifically, we examine different aspects of legacies at both the firm and country levels and their simultaneous impact on both initial speed to radical innovation and longer-term market performance.

By doing the above, we show that the failure to examine how different types of legacies - firm and country-level - play out over time can lead to an incomplete substantive picture of radical innovation as well as result in misleading implications for managerial practice. In particular, we make three contributions to the literature on legacy effects and radical innovation. First, we show that the current pessimistic view of legacy effects (e.g., see Christensen 1997; Foster 1986; Henderson and Clark 1990; Utterback 1994) is likely to be overstated. By unbundling the effects of different legacies in radical innovation and by linking the initial entry timing to eventual market performance, we aim to provide a more differentiated view of radical innovation. If legacies were indeed as negative as the existing research suggests, no incumbent would ever survive, let alone prosper in the next product generation. The frightening consequence is that firms' fates would be doomed from the point of initial innovation onwards (Christensen 1997; Schumpeter 1934). Second, we show that ignoring country-level legacy could lead to a managerial "one size fits all" approach, which fails to appreciate institutional, infrastructural, and market differences among heterogeneous national contexts. By aggregating data from six European countries with different legacies, for example in post-1980s direct banking technologies, we seek to construct a representative model for an industry-wide innovation spilling over from one country to another. Overall, our research confirms the view that country differences do matter in radical innovation and should be considered accordingly by managers. Third, we contribute by linking entry timing directly to the related issues of subsequent performance and longer-term survival (cf. Golder and Tellis 1993 ) instead of only focusing on first-movers at a point in time (e.g., see Lieberman and Montgomery 1988, 1998; Robinson et al. 1994; and Kerin et al. 1992). Whereas first-movers 
may exhibit speed initially, for example, they could equally show inferior performance in the longer term and may even exit the market after the researchers' one-shot observation in the early stages of the evolution of the technology. Likewise, our approach to capturing individual speed to entry as a continuous variable complements past research on entry order ranks (e.g., Bowman and Gatignon 1996; Kalyanaram et al. 1995; Lilien and Yoon 1990; Szymanski and Troy 1995).

\section{Theory and Hypotheses}

\section{Definitions}

\section{Concept of Legacy}

We define legacy as the cumulative effects of the past on the present and future. The common dictionary definition (e.g., Merriam-Webster) refers to legacy as "something transmitted by or received from an ancestor or predecessor or from the past". Similarly, prior research has argued that "a firm's system of strategic attributes evolves over time as it continually incorporates new strategic assets and new products" (Roberts and Amit 2003, p. 108). We apply this notion of legacy on two levels, that is, firm legacy and country legacy. Certain past phenomena, whether a particular technology, bundles of specific resources, or organizational characteristics, create a lasting effect onto the path-dependent trajectory of firms. Of course not everything from the past is relevant to the focal radical innovation. By implication or by implicit definition, we consider only those aspects of the past that are relevant for radical innovation.

The term legacy is also in the context of information technology. Legacy systems, for example, often lack competitiveness and compatibility with their modern equivalents, yet they continue to be used by firms because of the high cost of replacing or redesigning them. The implication is that the legacy system is large, monolithic and difficult to modify (e.g., see Bianchi et al. 2003; Brooke and Ramage 2002; Schneidewind and Ebert 1998; and Serrano et al. 2002). We argue, however, that the concept of legacy has multiple facets beyond technology. One such example in marketing relates to the negative legacy of consumption in the context of social evolution and environmental aspects (Anderson and Challagalla 1994).

\section{Radical Innovation}

Following the definition provided by Chandy and Tellis (1998, 2000), radical innovations can be conceptualized along two common dimensions: technology and markets. A radical innovation incorporates both a substantially different technology and a substantial 
increase in customer benefits. In this research, we add the further dimension of time or speed to radical innovation. Thus, we are concerned with how quickly firms radically innovate by initially embracing the new technology.

Numerous other authors have also referred to the concept of radicalness in innovation in their research (e.g., see Colarelli O’Connor 1998; Damanpour 1991; Green and Gavin 1995; Henderson 1993; McDermott and Colarelli O’Connor 2002; Leifer et al. 2000; Munir and Phillips 2002). In light of numerous underlying definitions of innovation types in recent research, Garcia and Calantone (2002) and Gatignon et al. (2002) review the multiple approaches in the literature and offer clarification on the definitional differences between innovation types.

\section{Legacy Effects in Radical Innovation}

We propose three main types of legacy effects in the context of radical innovation: technology legacy, organizational legacy, and country legacy.

\section{Technology Legacy}

The diffusion of innovations (e.g., Bass 1969; Rogers 1995) creates managerial challenges for incumbent innovators (Christensen 1997). Thus, firms face the challenge of deciding when and how to adopt a new technology or to replace an old one. Our research focuses on the dynamics of technology adoption over time by differentiating between (1) prior innovations' legacy of focal innovations, (2) current, focal radical innovation, and (3) focal subsequent innovations. We envision a situation where incumbent firms have varying degrees of previous technologies in place at the time of adopting a focal radical innovation. By contrast, new market entrants or spin-offs may have no such legacy in place. In a later phase, the current focal innovation could become a legacy for subsequent innovations. The dynamics of interaction among emerging and mature technologies can be modeled based on their growth rates by three modes: pure competition, symbiosis, or predator-prey ${ }^{1}$ (cf. Pistorius and Utterback 1997). A number of empirical studies in the Industrial Organization literature have examined this rivalry among technologies in the context of banking (e.g., Hannan and McDowell 1984, 1987, 1990; Saloner and Shepherd 1995). It is important to note that the focal innovation in those studies was the adoption of automated teller machines (ATMs) by US banks which bears a clear linkage to the focal innovation in our empirical context.

${ }^{1}$ According to Pistorius and Utterback (1997: 72), the interaction modes among competing technologies can be distinguished as: 1 . Pure Competition, where an emerging technology has a negative influence on the growth of a mature technology and vice versa; 2. Symbiosis, where both technologies have a positive influence on each others' growth rate, and 3. Predator-Prey, where an emerging technology positively influences the growth of a mature technology, whilst the latter negatively impacts an emerging technology or vice versa. 


\section{Complementary versus Replacement Technologies}

Conceptually, we shall differentiate between a complementary and a replacement technology legacy in order to highlight their potentially different effects. These terms should be viewed as being similar to the interaction modes of symbiosis (complementary) and pure competition or predator-prey (replacement) as coined by Pistorius and Utterback (1997). The two terms also reflect the notion of competence-enhancing (=complementary) and competencedestroying (=replacement) technological continuities (cf. Arrow 1962, Henderson and Clark 1990; Schumpeter 1950; Tripsas 1997; and Tushman and Anderson 1986). Thus, complementary legacy technologies represent older generations of a technology which nonetheless could co-exist with a later, more advanced technology, such as our radical innovation in focus. On the other hand, a replacement technology is more likely to be rendered obsolete by the advent of the subsequent focal innovation.

\section{Organizational Legacy}

The second pillar of legacy relates to organization at the firm level. This paper focuses on two aspects of organizational legacy, the extent of financial control and operational control in the firm. A low degree of financial control, for example, would indicate that firms enjoy greater institutional freedom, that is, they are less directly influenced by shareholder concentration or centralization. Majority shareholders are likely to possess a certain weight in influencing important managerial decisions, such as the strategic move to adopt a new technology. On the other hand, management tends to enjoy comparatively more freedom with highly dispersed ownership structures, where the individual shareholder has minimal influence. We would argue that the extent of financial control is inversely related to management's flexibility to embrace radical innovations. Posed differently, institutional dependence is likely to induce managerial dependency and would thus allow less autonomy for critical strategic decisions. For example, previous studies have examined the impact of institutional ownership on firms' innovations (e.g., Kochhar and David 1996) and firm performance (e.g., Chaganti and Damanpour 1991).

Whereas financial control relates to organizational ownership, the extent of operational control is more closely linked to organizational structure. A high degree of operational control would indicate, for example, that a radical innovation is fully embedded in the firm's traditional operations. In this case, the firm would typically share one corporate identity and organizational culture within its operations. A low degree of operational control exists, for example, in the case of a spin-off operation, which may be deliberately placed outside of the traditional firm environment. Such a move intentionally reduces the influence of parents' organizational legacy and culture, especially in situations where a radical innovation may be 
marketed rather differently from traditional products. Overall, many authors have emphasized the challenging role of market incumbents seeking to exploit radical innovations (Christensen 1997; Ghemawat 1991; Henderson 1993). We thus intend to look beyond traditional market incumbency by also including all new market entrants in a particular industry ${ }^{2}$, which can be frequently spin-offs from traditional operations.

\section{Country Legacy}

The third aspect of legacy relates to cross-country differences in any international research context. A growing body of literature addresses the issue of innovation in a crossborder environment (for example, see Zander and Sölvell 2000 for an overview). In particular, authors have increasingly modeled the diffusion of technological innovations across multiple countries as opposed to purely domestic contexts (e.g., Dekimpe et al. 2000; Gatignon et al. 1989; Kumar et al. 1998; and Mahajan and Muller 1994). Another relevant study explains the variation in time-to-takeoff of new products in a cross-border European context based on a set of economic and cultural variables (Tellis, Stremersch and Yin 2003). This work extends the earlier model developed by Golder and Tellis (1997) from a purely domestic to a multinational context of 16 European countries. The concept of time-to-takeoff is similar to our notion of speed-to-radical innovation, except that the former research is placed in the product domains of new white and brown goods, whereas we are concerned with the adoption of radical innovations. In either case, there are institutional country factors that help to explain crosscountry variations. While institutional theory and the significance of the institutional environment to firms retain closer links to economics, this body of theory has also attracted recent interest in the management (Dacin et al. 2002) and marketing literature (Grewal and Dharwadkar 2002). Instead of using purely economic or cultural (e.g., Hofstede 1990) variables, our notion of country legacy relates to variations in market variables within the specific industry context. Moreover, country legacy aims to capture the varying degrees of readiness for the focal innovation.

\section{Resource Legacy (Controls)}

Finally, another notion of legacy, resource legacy, will be used to control for firm size while focusing on the previous three main types of legacy throughout our analysis. Resource legacy refers to firms' cumulative bundles of different resources over time and can be conceptualized by three types of resources: financial, physical (i.e., bricks-and-mortar), and customer resources. We refer to the extent of resource legacy as dominance, or the level of market power wielded by the firm (e.g., see Bain 1968; Scherer 1980). The origins of this tenet

\footnotetext{
${ }^{2}$ This is also referred to as ex novo entry, e.g., see Fuentelsaz et al. (2002).
} 
can be found in the hypothesis that sheer firm size (and thus market power) is a key driver for innovation (Schumpeter 1950). This concept has recently attracted considerable interest in the literature (e.g., see Chandy et al. 2003; Shamsie 2003; and Sorescu et al. 2003). We follow this stream of research but also emphasize the multi-faceted nature of the construct. As such, we encompass the aforementioned three aspects of dominance which allows us to separate the potentially different effects of certain resources.

\section{Conceptual Framework}

Figure 1 below depicts the basic conceptual framework of our research and visualizes the multi-faceted construct of legacy. Three main types of legacy, technology, organizational and country legacy simultaneously influence a firm's (initial) speed to radical innovation and (subsequent) market performance. Speed to radical innovation is both a dependent and independent variable, as it also drives market performance.

Figure 1: Conceptual Framework

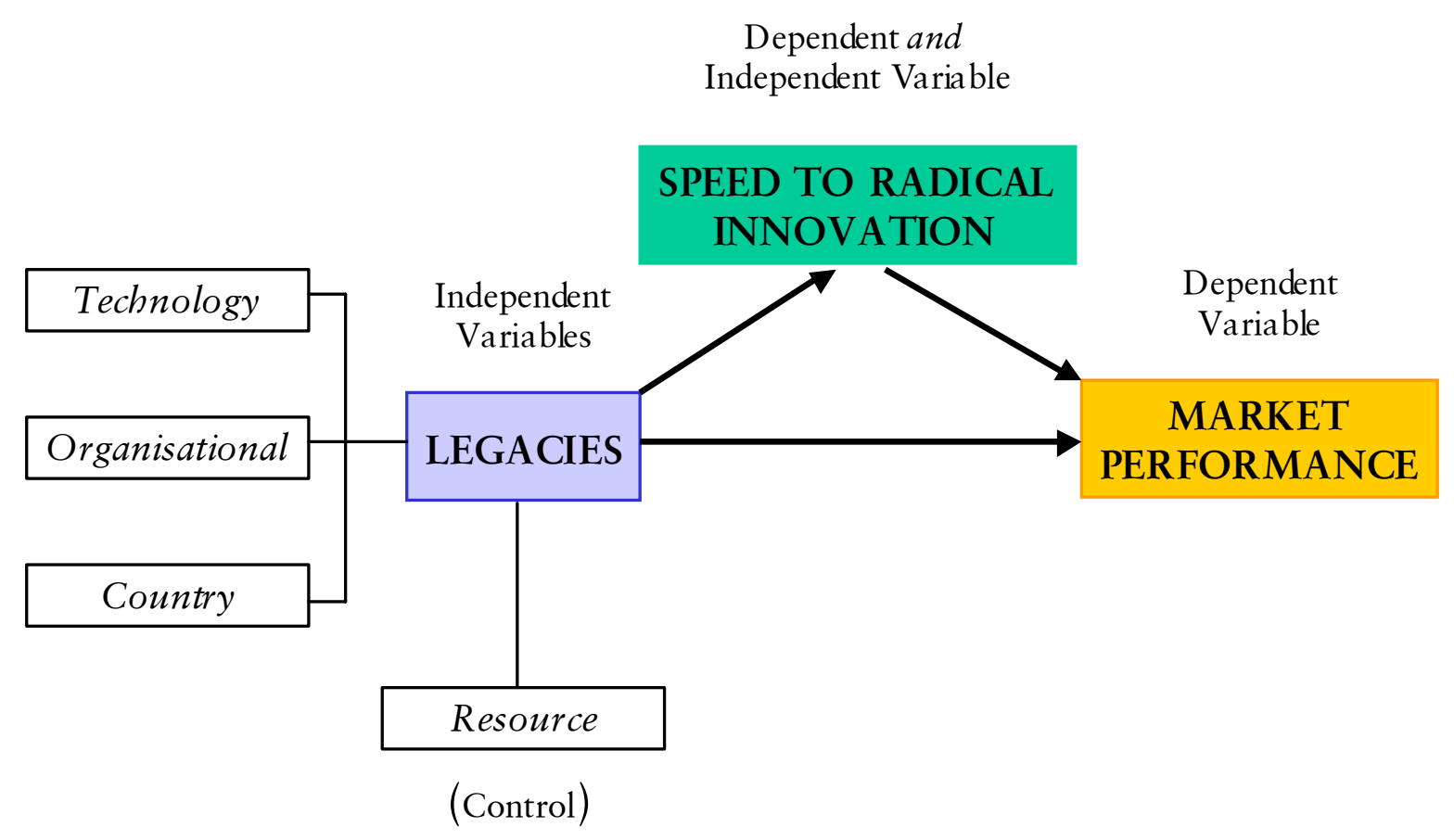




\section{Hypotheses}

\section{Technology Legacy and Speed}

There are numerous examples of industries in which firms that were successful in innovating with one technology failed to do so when a new technology emerged (Foster 1986; Utterback 1994). This empirical phenomenon illustrates the negative legacy effect discussed earlier, whereas we argue that such legacies may not always be as harmful as they are portrayed. Thus, in the face of rapid change, experience with certain prior technologies could also buffer incumbents from the effects of competence destruction (cf. Anderson and Tushman 1990). Such technologies could represent complementary assets whose possession alone may help incumbents survive industry upheavals and potentially embrace radical innovations faster (Teece 1986; Tripsas 1997). In addition to Tripsas' (1997) study on the typesetter industry, the concept of complementary assets was subsequently also tested in the pharmaceutical and biotechnology contexts (Rothaermel 2001a, 2001b). Teece's (1986) framework of complementary assets that confer an advantage upon dominant incumbents also identifies complementary technologies as such assets, among access to distribution channels or specialized capabilities, for example. The importance of complementary assets in surviving technological or market transitions was further expanded by adding prior experience as an important asset (King and Tucci 2000, 2002). The authors pose that experience in previous markets increased the probability that a firm would enter a new market and that market experience in the prior niche encouraged earlier entry. As such, we follow the rationale that the legacy of prior related experience in both markets and technologies helps incumbent survival, for example by creating an early awareness of emerging radical innovations. We would thus argue that experience with prior technologies represent a positive legacy on speed to radical innovation, and pose:

\section{$H_{1}$ : $\quad$ Firms with a greater extent of technology legacy are likely to adopt radical innovations faster in the first instance.}

\section{Technology Legacy and Performance}

Whereas experience in prior technologies is likely to create firms' awareness and thus facilitate their speed to radical innovation, the subsequent market performance is more likely to be affected by the different nature of prior technologies. In the longer run, replacement technologies could embody a competence-destroying effect within the firm and also lead to cannibalization effects in relation to the radical innovation. Moreover, a firm's customers may have become so accustomed to a prior replacement technology that they may hesitate to embrace the radical innovation and exhibit "balking" behavior (Dhebar 1996). On the other 
hand, complementary technologies are less likely to lead to cannibalization, for example with a firm's existing customers, and could thus enhance market performance mutually with the radical innovation. Therefore, we hypothesize a contrary effect of complementary versus replacement technologies on market performance:

\section{$H_{2 a}: \quad$ Firms with a greater extent of complementary technology legacy are likely to display superior market performance in the longer term. \\ $H_{2 b}: \quad$ Firms with a greater extent of replacement technology legacy are likely to display inferior market performance in the longer term.}

\section{Organizational Legacy and Speed}

We earlier discussed the two components of organizational legacy, i.e., financial control and operational control. We argue that firms with a highly dispersed ownership by shareholders tend to enjoy greater maneuverability in strategic entry decisions related to radical innovations. In contrast, firms with a high concentration of very influential shareholders are less likely to be granted such decision-making latitude and may thus embrace radical innovations more slowly. Therefore, the organizational legacy of financial or ownership control could be regarded as a driver of organizational innovativeness (e.g., see Damanpour 1987, 1991; Deshpandé et al. 1993).

The structural element of operational control in organizational legacy follows a similar rationale. Controlling for resources (i.e., firm size), a low degree of operational control is also likely to promote faster innovation speed, for example in a spin-off operation. While speed in a traditional incumbent operation may be adversely affected by organizational inertia (e.g., see Chandrashekaran et al. 1999; Tripsas and Gavetti 2000) and escalation of commitment (e.g., see Brockner 1992; Camerer and Weber 1999; Schmidt and Calantone 2002; Staw, 1981), a spin-off could be considered a relative "safe haven" for experimenting with radical innovations. The spin-off solution, for example, does typically not jeopardize existing brand equity or cannibalize existing customers.

\section{Organizational Legacy and Performance}

Numerous studies have observed the empirical phenomenon of declining performance by traditional incumbents in the face of radical innovations (e.g., see Christensen 1997; Cooper and Schendel 1976; Foster 1986; Henderson and Clark 1990; Tushman and Anderson 1986). Moreover, new entrants or spin-off operations frequently pioneer radical innovations, whereas incumbents tend to focus on incremental innovations (Dewar and Dutton 1986). In summary, we would argue that the organizational flexibility from low financial and operational control allows for quicker innovative speed and superior subsequent performance and thus pose: 
$\mathrm{H}_{3}$ : $\quad$ Firms with a lower degree of financial and operational control are likely to adopt radical innovations faster in the first instance.

$\mathrm{H}_{4}$ : $\quad$ Firms with a lower degree of financial and operational control are likely to display superior market performance in the longer term.

\section{The Role of Country Legacy}

We argued earlier that country-level legacies refer to institutional differences across national settings, such as varying degrees of market and technology infrastructure. In relation to market infrastructure, for example, the underlying product market size ${ }^{3}$ of the industry represents one important country legacy. In line with the diffusion of innovation literature (e.g., Rogers 1995), also in the extended context of cross-border environments (e.g., Zander and Sölvell 2000), we hypothesize a positive relationship between product market size and speed of diffusion within each country. If the underlying product market is large, then firms have a higher incentive to enter early whilst capturing the lucrative market segments faster than their rivals. Consequently, we pose:

$H_{5}$ : Firms are likely to adopt radical innovations faster in the first instance if the country's underlying product market is larger.

The second aspect of market infrastructure apart from differences in scope and size refers to market concentration. Overall, firms should be able to extract monopolistic rents and thus display superior average performance if there are only few players in the market. In contrast, less concentrated industries with many players should result in inferior performance due to a state of near perfect competition. Controlling for population differences, we thus pose:

$H_{6}: \quad$ Firms with less market players per population in their country are likely to display superior market performance in the longer term.

Besides the market dimension, the second element of country legacy relates to the impact of institutional differences across countries' technology infrastructures on innovation speed and market performance. We shall not address or test these hypotheses separately, as it appears obvious, for example, that a more advanced technological country infrastructure would also help faster innovative activity. Nonetheless, the notion of differences in technology infrastructure across countries will be later included in the fully specified model.

\footnotetext{
${ }^{3}$ It is important here to distinguish between the concepts of product market size versus country market size. We refer to the product market of our empirical context which tends to be highly correlated with the country market in our Western and Northern European scope. In the case of China, however, the country market may significantly differ from the product market.
} 


\section{Method}

\section{Empirical Context}

To test out hypotheses, we chose the context of online retail banking. This industry provides several benefits as an empirical context. First, the focal innovation of Internet banking was preceded by earlier direct banking technologies, namely PC home banking and telephone banking. These initial modes of non-branch or distance banking represent different technology legacies in relation to the radical innovation of Internet banking. We use this term because (1) such legacies represent previous technological generations following the same logical path of innovation, and (2) their enduring "inheritance" also affects the development of the subsequent radical innovation. Following our definition of radical innovation, only the application of Internet banking as a new technology substantially affected customer need fulfillment. The supporting evidence can be found in explosive customer adoption levels across multiple countries for Internet banking vis-à-vis rather modest evolutions for earlier direct banking generations (Kalakota and Frei 1997).

Second, we are able to examine entry and performance in a comprehensive manner in European Internet banking. Past adoptions of new technologies often required several decades to reach significant levels of customer need fulfillment (e.g., telephone, television, or automated teller machines in banking). In contrast, most European retail banks adopted Internet banking quickly, i.e., during our investigation horizon between January 1996 and December 2001. This ensures that most market players had adopted the radical innovation within this timeframe and allows us to jointly examine speed of entry in relation to longitudinal performance in one study.

Third, the retail Internet banking context enables us to use objective performance indicators that adequately reflect customer need fulfillment. The latter can be best established by focusing on the market with the highest number of individual customers: personal consumer banking. This segment is also more transparent to outsiders than the commercial or investment banking niches for corporate customers. Overall, using the retail banking sector allows us to evaluate market performance in terms of direct customer adoption. Such measures are also more objective because they are directly linked to the focal innovation, whereas purely financial performance indicators, for example, tend to be diluted aggregates of multiple divisions within a banking group and typically unrelated to specific radical innovations.

Fourth, European Internet banking exemplifies sufficient country and firm variance among the main variables of legacy, speed to radical innovation, and market performance. 
Such variance is ensured by different Internet banking adoption patterns per country, depending on the level of Internet readiness, and a combination of traditional incumbent banks versus new entrants in the form of spin-off operations. Therefore, the chosen empirical context is suitable to test the hypothesized effects on entry speed and market performance.

Final, retail banking is an important industry which contributes to a large part of a country's GDP and the employed workforce. Furthermore, rich endowments of financial resources and high industry profitability have enabled retail banks to continuously innovate: credit cards, automatic teller machines, and electronic payments are past examples of innovative products, channels, and technologies (Banks 2001). In using banking as a suitable empirical context for testing conceptual ideas, we also follow a stream of authors in the innovation literature, such as Han et al. (1998), Hitt and Frei (2002), and Damanpour and Gopalakrishnan (2001), Gopalakrishnan and Bierly (1997), and Roberts and Amit (2003).

\section{Sample}

\section{Country Sample}

Europe is a suitable geographic context for this research. It represents one unified economic market, yet the different national economies, each endowed with different country legacies, contribute a rich cross-country variance within the sample. Moreover, the European banking sector also allows for sufficient sample variance within countries, as reflected in the competitive dynamics of each country market. Such heterogeneity should allow us to gain valuable insights when adopting a complete, longitudinal view of entry and performance. Thus, our objective was to achieve a broad representation of European banking by including the pioneering countries and the largest markets. We based our selection on the following criteria:

\section{$\Rightarrow$ Absolute market size in retail banking (i.e., population, number of banks, volume of customer deposits with banks); \\ $\Rightarrow$ Relative online penetration levels (Internet usership); and \\ $\Rightarrow$ Existence of technology legacies, i.e., institutionalized pre-Internet home banking technologies and experience \\ $\Rightarrow$ Geographic emphasis on Western and Northern Europe}

The final sample included six countries: Denmark, Finland, France, Germany, Sweden, and the United Kingdom. Our conceptual variables and derived hypotheses require a sample with sufficient variance among and within country markets and high adoption rates of the radical innovation. Institutionalized technology legacies by country are present in Germany and France, for example, as both countries have a history of home banking solutions from the early 
1980s based on videotex technologies ${ }^{4}$. Furthermore, Scandinavia became an early European leader in online penetration rates and Internet banking applications with Finland closely followed by Sweden, and by Denmark. Furthermore, the United Kingdom, Germany and France form the largest retail banking markets in Europe, as measured by population, number of banks, and customer deposits. Any subsequent suitable candidates for sample inclusion would have been the Netherlands, Spain and Italy in order to create a truly pan-European scope. Due to limited time and resources, however, we could not include the latter countries but also for the following reasons: they could not further enrich the notion of country legacy, especially concerning pre-Internet home banking technologies. Furthermore, most banks in these countries followed the example of the European pioneers included in our sample, thus the entry patterns are likely to he highly concentrated between 1999 and 2001, as opposed to a broader range of the investigation horizon from 1996 to 2001. Lastly, Spain, Italy and the Netherlands represent medium to large European banking markets in comparison to Germany, France and the United Kingdom and also lagged initially behind the European pioneers in online penetration rates. In comparison to other regions, Table 1 below underlines the relative dominance of Western Europe in terms of online banking users which consistently make up about half of total worldwide users. It is also important to note that the Unites States has only about half as many online banking users as Western Europe while the existing gap continues to widen.

Table 1: Worldwide Online Banking 2000-2004

\begin{tabular}{||l|r|r|r|r|r||}
\hline $\begin{array}{l}\text { Region } \\
\text { (MILLIONS OF USERS) }\end{array}$ & 2000 & 2001 & 2002 & $2003 *$ & $2004 *$ \\
\hline Western Europe & 18.6 & 28.0 & 37.8 & 47.7 & 57.9 \\
\hline United States & 9.9 & 14.7 & 17.1 & 20.4 & 22.8 \\
\hline Japan & 2.5 & 6.5 & 11.9 & 19.6 & 21.8 \\
\hline Asia-Pacific (excl. Japan) & 2.4 & 4.4 & 6.8 & 9.8 & 13.8 \\
\hline Rest of the world & 1.0 & 1.7 & 3.1 & 5.1 & 6.1 \\
\hline Total & 34.4 & 55.3 & 76.7 & 102.6 & 122.3 \\
\hline
\end{tabular}

Source: International Data Corporation (www.idc.com); * projected figures

\footnotetext{
${ }^{4}$ For example, Bildschirmtext (Btx) in Germany and Minitel in France.
} 


\section{Firm Sample}

We selected the firm sample by applying a systematic and rigorous procedure for each country. Figure 2 shows the individual steps followed in order to arrive at the final sample.

Figure 2: Firm Sample Selection Process (by Country)

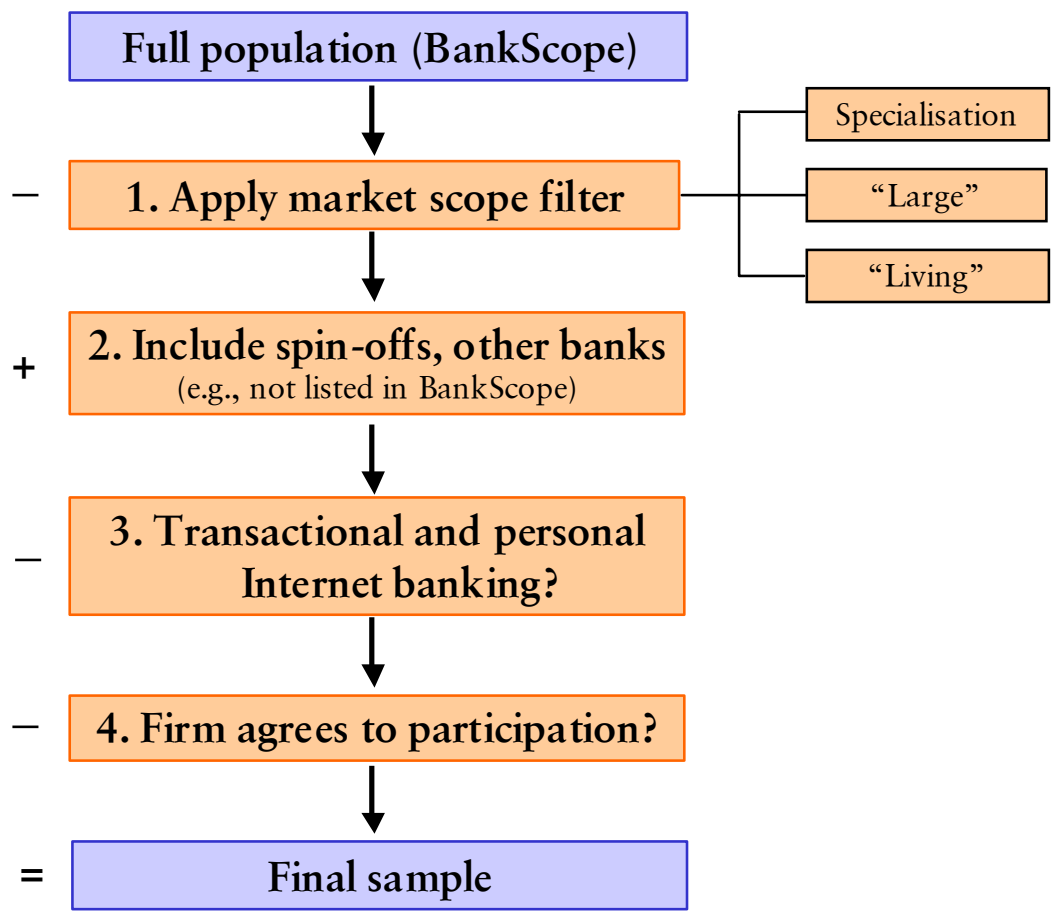

For each country, we started with the full banking population using BankScope ${ }^{5}$, a financial database containing over 13,000 individual banks worldwide. We then narrowed the sample in Step 1 by applying a market scope filter based on three criteria: 1. Banking specialization $^{6}$ (including only commercial banks, savings banks and cooperative banks in order to properly reflect the retail banking sector); 2. Large banks ${ }^{7}$ (including only banks with total assets in excess of USD 1 billion for the last available year); and 3. Living banks (as per December 2001, in order to exclude banks that had exited the market but are still contained in the database).

\footnotetext{
${ }^{5}$ BankScope is a product of Bureau van Dijk Electronic Publishing (www.bvdep.com) and probably the most comprehensive and detailed database that can be found in the banking sector worldwide.

${ }^{6}$ In the case of Germany and France, we initially included commercial banks only due to the large number of independent savings and cooperative banks. We subsequently added the main savings and cooperative banks manually for those two countries.

${ }^{7}$ The "large bank" definition is commonly used in the banking sector as a threshold and eliminates the large number of smaller players in the overall population distribution. Smaller and local banks, for example, tend to adopt the focal innovation of Internet banking rather slowly due to low initial customer demand and lack of resources for the required high investments upfront.
} 
After the first step of narrowing the sample, we then utilized the directories of national banking associations and other industry sources such as Nielsen//NetRatings to add other relevant banking players in Step 2 which were not included in the BankScope database ${ }^{8}$. All Internet banking spin-offs from traditional banking players which had only recently entered the market were automatically included at this stage regardless of size. All such banks contain an explicit focus on the Internet as primary distribution channel. This measure ensured sufficient variance between incumbents and new entrants and most of the 22 spin-off banks included in the final sample of 123 banks were not listed in BankScope.

In Step 3 we included only banks who had fully implemented at least one transactional Internet banking facility to personal (i.e., non-business) customers before January 2002. Our definition of Internet banking refers to basic retail operations of online current and savings accounts, which can be clearly identified and are directly comparable across banks. Thus, we excluded other banking products like loans, mortgages, or credit cards that typically embody only partial online features and are not easily comparable across banks. Furthermore, our definition of Internet banking excludes Internet brokerage facilities or e-brokerage-only banks ${ }^{9}$.

At this stage, we had included the entire population of living, large retail banks with transactional Internet banking in each country. In Step 4, all of those banks were contacted individually and then included in the final sample if they agreed to participate in our research. As such, we aimed to obtain as many participating banks as possible but could, however, not ensure full market coverage. Table 2 illustrates the detailed sample filtration process by country and shows how many banks were dropped in each stage. The differences between the bottom two rows reflect the transactional Internet banking criterion and the ultimate firm participation.

${ }^{8}$ One example of manually included banks is the case of mortgage banks or building societies in the United Kingdom, if they had sufficiently diversified into standard retail banking products, such as current and savings accounts. Another example refers to banks or non-traditional banking players which were clearly active in the respective local market and satisfied all the previous criteria but for some reason were not listed in BankScope.

${ }^{9}$ We base our rationale for the pure Internet banking focus on the fact that e-brokerage involves a different underlying business model compared to standard retail banking, i.e., a transaction volume-driven and fee-based model versus one based on monetary volumes and net interest margins. Furthermore, any performance effects with Internet brokerage banks are highly (probably solely) correlated with stock market performance instead of reflecting true variance in firm performance. 
Table 2: Firm Sample Filtration Process by Country

\begin{tabular}{|c|c|c|c|c|c|c|c|}
\hline & & & & & \multicolumn{2}{|c|}{$\begin{array}{r}\text { Worldwide: } \\
\text { European Union: } \\
6 \text { Country Sample: }\end{array}$} & $\begin{array}{r}15,885 \\
7,969 \\
5,403 \\
\end{array}$ \\
\hline \multicolumn{8}{|c|}{ Number of Banks } \\
\hline & Denmark & Finland & France & Germany & Sweden & $\begin{array}{c}\text { United } \\
\text { Kingdom }\end{array}$ & Total \\
\hline Population & 273 & 29 & 1,273 & 2,823 & 75 & 930 & 5,403 \\
\hline -Specialized & 233 & 21 & 474 & 364 & 33 & 513 & 1,608 \\
\hline -Large & 34 & 10 & 111 & 89 & 12 & 84 & 340 \\
\hline -Living & 31 & 8 & 83 & 74 & 10 & 74 & 280 \\
\hline+ Spin-offs & 37 & 8 & 88 & 80 & 10 & 79 & 302 \\
\hline + Others & 47 & 8 & 92 & 90 & 11 & 83 & 331 \\
\hline Final Sample & 22 & 6 & 18 & 42 & 10 & 25 & 123 \\
\hline
\end{tabular}

Source: BankScope, Release 141.1, April 2002 (excluding “spin-offs” and “other banks”)

Based on the 123 banks included in the final sample as shown in Table 2, we now illustrate the balanced sample distribution in Figure 3 while combining the three Scandinavian countries.

Figure 3: Firm Sample Distribution in $\%(n=123)$

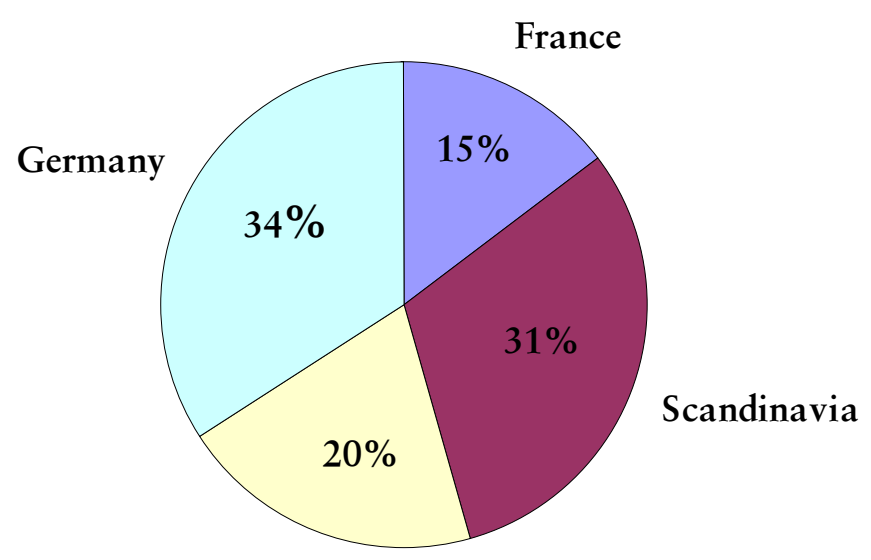

United Kingdom 
Table 3 below reveals the sample composition by country based on three types of market players: dominant incumbents, non-dominant incumbents, and spin-offs or new entrants. All of the representative banks in the three categories above are contained in the total sample of 123. The table with prototypical examples allows the knowledgeable reader to quickly establish that the main players are included, thereby adequately reflecting the competitive dynamics of each domestic market. The listed banks appear in alphabetical order and not in order of financial dominance. The dominance categorization is based on both total assets at Internet banking entry year and end-2001.

Table 3: Three Categories of Representative Banks in Sample by Country

\begin{tabular}{|c|c|c|c|}
\hline Country & $\begin{array}{l}\text { Dominant } \\
\text { Incumbents }\end{array}$ & Non-dominant Incumbents & $\begin{array}{l}\text { New Entrants/ } \\
\text { Spin-offs }\end{array}$ \\
\hline $\begin{array}{l}\text { United } \\
\text { Kingdom }\end{array}$ & $\begin{array}{l}\text { Abbey National } \\
\text { Barclays } \\
\text { HSBC } \\
\text { Royal Bank of Scotland }\end{array}$ & $\begin{array}{l}\text { Alliance \& Leicester } \\
\text { Co-operative Bank } \\
\text { Nationwide } \\
\text { Standard Life Bank }\end{array}$ & $\begin{array}{l}\text { Cahoot } \\
\text { Egg } \\
\text { Intelligent Finance - IF } \\
\text { Smile }\end{array}$ \\
\hline Germany & $\begin{array}{l}\text { Commerzbank } \\
\text { Deutsche Bank } \\
\text { Dresdner Bank } \\
\text { HypoVereinsbank }\end{array}$ & $\begin{array}{l}\text { BW-Bank } \\
\text { National-Bank } \\
\text { norisbank } \\
\text { Sparda Bank } \\
\end{array}$ & $\begin{array}{l}\text { AdvanceBank } \\
\text { DAB Bank } \\
\text { Comdirect } \\
\text { Netbank } \\
\end{array}$ \\
\hline France & $\begin{array}{l}\text { Banque Populaire } \\
\text { BNP Paribas } \\
\text { Crédit Lyonnais } \\
\text { Société Générale }\end{array}$ & $\begin{array}{l}\text { Banque Cortal } \\
\text { Crédit Commercial de } \\
\text { France - CCF } \\
\text { Crédit du Nord } \\
\text { Crédit Industriel et } \\
\text { Commercial - CIC }\end{array}$ & $\begin{array}{l}\text { Banque AGF } \\
\text { Banque Bipop } \\
\text { Zebank } \\
\text { e.creditlyonnais.fr }\end{array}$ \\
\hline Finland & $\begin{array}{l}\text { Nordea (Finland) } \\
\text { Okobank Group } \\
\text { Sampo Bank }\end{array}$ & $\begin{array}{l}\text { Aktia Savings Bank } \\
\text { Alandsbanken } \\
\text { Mandatum Bank }\end{array}$ & (none) \\
\hline Sweden & $\begin{array}{l}\text { FöreningsSparbanken } \\
\text { Handelsbanken } \\
\text { Nordea (Sweden) } \\
\text { SEB }\end{array}$ & $\begin{array}{l}\text { IKANO Banken } \\
\text { Matteus Bank } \\
\text { Skandiabanken } \\
\text { Sparbanken Finn } \\
\end{array}$ & (none) \\
\hline Denmark & $\begin{array}{l}\text { BG Bank } \\
\text { Danske Bank } \\
\text { Nordea (Denmark) } \\
\text { Jyske Bank }\end{array}$ & $\begin{array}{l}\text { Alm. Brand Bank } \\
\text { Lån \& Spar Bank } \\
\text { Nykreditbank } \\
\text { Spar Nord Bank }\end{array}$ & $\begin{array}{l}\text { 1792.dk } \\
\text { Basisbank } \\
\text { Day2Day Bank } \\
\text { Nextbank }\end{array}$ \\
\hline
\end{tabular}




\section{Measures}

After determining the country and firm sample we now create appropriate measures in order to test the hypotheses derived in section 2. Our dataset contains a combination of longitudinal archival and survey data.

\section{Data Collection}

The first transactional Internet banking site in Europe began in Finland in February 1996. Therefore, we compiled annual company data from BankScope for the year of pioneer entry until the latest available, i.e., 1995 to 2001. If the required data were not available in BankScope, they were collected manually from corporate records or via individual (telephone or e-mail inquiry) with the banks.

Due to lack of public availability, all data related to entry timing and customer figures were collected via telephone interviews or by sending e-mail questionnaires addressed to an appropriate contact person in the bank. This contact person would typically be the "Head of Internet Banking", if that position existed. Alternatively, it could be a senior press or marketing officer who would act as liaison person to the technical departments in the bank. We employed a data sheet per bank in order to comprehensively compile the required entry timing and customer numbers which usually took a number of iterative follow-ups with respondents. In all cases, we assured respondents that any data supplied would only be used for research purposes, kept fully confidential and only disclosed in aggregate and anonymous form. It sometimes took enormous personal effort to give banks these assurances and obtain the ultimate release of critical information, such as highly sensitive total customer figures and entry timing data.

In the following sections, we describe the measures and their operationalization, starting with the dependent variables speed to radical innovation and market performance (for a complete overview, see Table 5).

\section{Speed to Radical Innovation}

We started by collecting the individual launch dates for the banks' first transactional Internet banking facility in the format month-year in order to ensure sufficient level of detail in entry timing. The relevant entry date referred to the full public launch and not any prior piloting phase or partial launch. Using December 2001 as a fixed end date of our investigation horizon, we then created a continuous timing variable in number of months as shown in Figure 4. This measure reflects the degree of Internet banking experience of any bank as per December 2001, i.e., the higher the number, the higher the entry speed to radical innovation. 
Figure 4: Calculation of Entry Speed (Example)

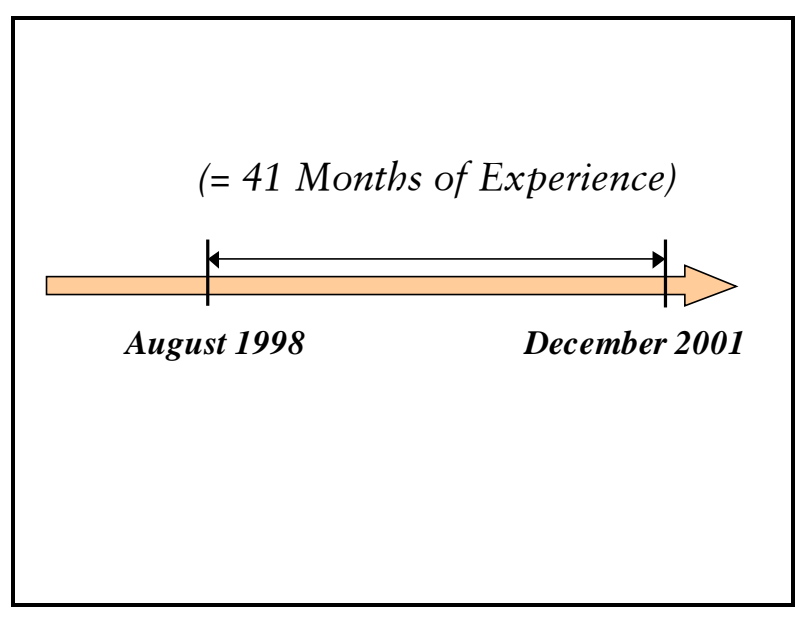

\section{Market Performance}

The adoption of the focal innovation is best measured by how many customers have embraced it at any given point in time. We chose the cumulative number of registered (personal) Internet banking customers at the end of 2001 as an appropriate measure for market performance. These are bank customers, either new or existing, who have deliberately registered with the bank for this innovation. Banks' aggregate financial performance data as potential measures for market performance are not publicly available for the specific context of Internet banking as a subset of the entire bank. Our choice is supported by a survey conducted by Forrester, an Internet research firm, who asked US banks in May 2002 how they measured the success of their online services:

Table 4: US Banks' Measure of Success of Online Services

\begin{tabular}{|l|l||}
\hline Metric & Total \\
\hline Number of online customers & $60 \%$ \\
\hline Penetration across customer base & $47 \%$ \\
\hline Percentage of active users & $43 \%$ \\
\hline Percentage using bill-pay & $37 \%$ \\
\hline Volume of bill pays & $30 \%$ \\
\hline Number of services per customer & $27 \%$ \\
\hline
\end{tabular}

Source: Forrester (May 2002), www.forrester.com

Because the distribution of Internet banking customers as a continuous variable is highly skewed to small numbers with a long "tail" along the $\mathrm{x}$-axis, we performed a $\log _{10}$ transformation in order to avoid heteroskedasticity. 


\section{Technology Legacy}

We measured technology legacy as the extent of experience in pre-Internet banking technologies. As outlined in section 2, the two dimensions of technology legacy relate to their complementary (telephone banking) or replacement character (PC home banking) vis-à-vis the focal radical innovation (Internet banking). Following the same procedure as for entry speed (see Figure 4), we created continuous timing variables based on the respective telephone and PC banking entry dates. This yields the number of months of complementary or replacement legacy as per December 2001 and ignores the possibility that some banks may have discontinued their PC service beforehand. Our method also ensures that all three timing variables are based on the same scale.

\section{Organizational Legacy}

We used the "BankScope independence indicator" as our measure of financial control which is inversely related to institutional (and thus managerial) independence. In other words, the lower the extent of financial control, the higher the independence measure according to BankScope. Overall, the independence indicator signifies the degree of independence of a company with regard to its shareholders. For example, a highly independent measure is attached to a firm in which no single shareholder holds an ownership of over $24.9 \%$. A further differentiation is applied with respect to the number of identified shareholders whose ownership percentage is known. In contrast, a highly dependent measure is attached to any company with a recorded shareholder with an ownership (direct or total) of over $49.9 \%$. It is also given to a company when a source indicates that the company has an ultimate owner. Finally, we converted the indicator into a numerical scaled measure ranging from 1 (highly dependent) to 9 (highly independent).

Regarding the second aspect of organizational legacy, operational control, we applied a dummy variable to indicate whether a firm represents a spin-off operation or not. This label refers to a spin-off who embraces the Internet as its sole or primary channel in banking and is thus differentiated from traditional incumbents.

\section{Country Legacy}

Country legacy refers to the influence of the institutional environment in each country on Internet banking adoption along two dimensions: technology infrastructure and market infrastructure. In terms of market infrastructure, the six European banking product markets in our sample exhibit considerable variance in size, which is naturally driven by their population and number of competing banks. For example, Finland, Sweden and Denmark together comprise a population of less than 20 million, whereas Germany alone boasts over 80 million 
people. The same discrepancies apply to industry structure and relative competition in banking. Finland, Sweden, and Denmark have highly oligopolistic markets and only limited number of banks in total. Moreover, the top three banks in each of those Scandinavian countries account for $86 \%, 65 \%$, and $60 \%$, respectively, of 2001 market share in retail deposits. The equivalent concentration ratio in Germany for 2001 is $24 \%$ with a market of over 2,500 banks (over $3,500$ in 1996$)^{10}$. In order to capture the underlying country legacy for market infrastructure, we created the construct product market size. Accordingly, we performed a factor analysis of each country's total deposits, total assets, total number of banks, and total number of branches for the year 1995. All four variables loaded highly on the first extracted principal component, explaining almost $92 \%$ of total variance ${ }^{11}$. In addition, we include bank coverage, a variable reflecting the competition in the banking market but also controlling for by the large differences in population levels. For each country, this measure is calculated as number of banks per 1 million of population in 1995 and varies from 3.2 (Finland), to 4.6 (Sweden), and 65.0 (Germany).

In terms of technology infrastructure, the extent to which different European countries embraced the Internet over time shows considerable variance. In Scandinavia, for example, the government and education sector actively promoted the use of Internet technologies. In contrast, France had the state-sponsored national Minitel network and thus did not push Internet adoption heavily. Other factors include the role of Internet service providers by country and the associated connection costs. In general, several variables could measure the extent of Internet "readiness" by country in terms of its national infrastructure: Internet penetration, number of Internet hosts, and PC possession. Hosts and PC possession are significantly correlated with Internet penetration at $r=0.86$ and 0.47 respectively (both $p<$ 0.001). Therefore, we included only Internet penetration to reflect each country's level of technology infrastructure ${ }^{12}$. Specifically, we used each country's penetration rate for 1995 across the entire sample, as the year preceding first Internet banking entry in Europe.

\section{Resource Legacy (Controls)}

We used the resource legacy variables as controls for firm size while focusing on the other three legacies throughout our analysis. Financial dominance is the first measure of firm size and stems from the Schumpeterian notion of monopoly power serving as impetus for

\footnotetext{
${ }^{10}$ Sources: Deutsche Bundesbank, Finnish Bankers' Association (Suomen Pankkiyhdistys), Swedish Bankers’ Association (Svenska Bankföreningen), Danish Bankers’ Association (Finansrådet), and Bankscope.

${ }^{11}$ The communalities for the four variables comprising market size are: total assets: 0.976; deposits: 0.813; number of banks in market: 0.906 ; and total branches: 0.979 .

12 The data for Internet penetration, number of hosts and PC possession were obtained from Euromonitor (www.euromonitor.com), an independent provider of global strategic research.
} 
continuous technological progress (Schumpeter 1950). In the innovation literature, for example, a common measure of firm size is number of employees (e.g., see Cohen and Levin 1989; Pavitt, Robson, and Townsend 1987). However, this measure is more appropriate in knowledge-intensive industries, such as pharmaceuticals, as human resources alone would not adequately reflect financial dominance for banks.

Another common measure for dominance is market share (Szymanski and Bharadwaj 1993). A novel view is emerging in the Industrial Organization literature that dominance, as a proxy for firm size, should in fact be viewed as a multidimensional construct (Borenstein 1990, 1991; Pleatsikas and Teece 2001). These authors suggest the following three dimensions of financial dominance: market share, assets and profits, all of which are suitable for the empirical context of retail banking. Market share among retail banks does not refer to sales or revenues but is commonly measured by customer deposits taken. In addition, bank size is commonly measured by national banking associations as total assets, i.e., reflecting an accounting value for a bank's total balance sheet. Due to its accounting nature, this is a more stable measure than market capitalization, for example, which is in fact a measure of stock market power. Profits as a third dimension relate to bank's financial resources and thus their ability to invest in Internet banking operations. All financial data of the six European countries were transformed into Euro (or Ecu prior to January 1999) at the official year-end exchange rates with the corresponding local currencies.

We applied this multidimensional view of financial dominance at the time (i.e., year) of radical innovation entry and conducted a factor analysis of deposits, total assets, and profits in order to obtain one factor score for our financial dominance construct. All three variables loaded highly on the first extracted principal component, explaining about $92 \%$ of total variance. ${ }^{13}$ During this step, we applied the deposits, assets, and profit data for the respective banks' fiscal year of Internet banking entry. We explain the rationale for using financial dominance data at Internet banking entry by our aim to measure banks' market power as closely as possible to management's strategic decision in favor of adopting the radical innovation. In contrast, applying a fixed date for all banks, e.g., 1995 as the year preceding first European entry, would have encountered a number of difficulties. First, most new entrants, or pure plays, would have not existed in 1995. Secondly, banks underwent a series of mergers and acquisitions in all of the six European countries. Therefore, a bank entering Internet banking in 1999, for example, was in many cases transformed into a completely different entity compared to 1995, hence not mirroring its financial dominance close to

13 The communalities for the three variables comprising the financial dominance factor score are: customer deposits: 0.962 ; total assets: 0.934 ; profits: 0.861 . 
Internet banking launch adequately. The third reason relates to different patterns of entry timing by country, whereby 1995 would be an appropriate pre-entry date for Finland and Sweden, for example, but unfortunately not for the United Kingdom or Denmark.

The remaining two resource legacies - bricks \& mortar dominance and customer dominance - have straight-forward measures: they simply count the total number of physical bank branches and the total number of retail customers by firm.

\section{Subsequent Innovation}

Our measure of subsequent innovation efforts by firms simply counts the number of post-radical innovations after the initial adoption of Internet banking. The created scaled measure is a number between 0 and 4 , as the possible innovations include:

$$
\begin{aligned}
& \Rightarrow \text { Mobile banking (GSM standard) } \\
& \Rightarrow \text { Mobile banking (WAP standard) } \\
& \Rightarrow \text { Mobile banking by PDA (personal digital assistant) } \\
& \Rightarrow \text { Banking by interactive digital TV (iDTV) }
\end{aligned}
$$

Table 5 below summarizes the measures and sources by construct and variable employed, as discussed in the previous paragraphs. 
Table 5: Overview of Constructs, Variables, Measures and Sources

\begin{tabular}{|c|c|c|c|}
\hline Constructs & Variables & Operational Measures & Sources \\
\hline Innovation & $\begin{array}{l}\text { Radical Innovation } \\
\text { Speed }\end{array}$ & $\begin{array}{l}\text { Total Internet banking experience in } \\
\text { months at the end of } 2001 \text { based on } \\
\text { initial entry date (February 1996) }\end{array}$ & $\begin{array}{l}\text { Survey and company } \\
\text { records }\end{array}$ \\
\hline Performance & $\begin{array}{l}\text { Market } \\
\text { Performance }\end{array}$ & $\begin{array}{l}\text { Total number of registered personal } \\
\text { Internet banking customers at the end } \\
\text { of } 2001\end{array}$ & $\begin{array}{l}\text { Survey and company } \\
\text { records }\end{array}$ \\
\hline \multirow[t]{2}{*}{$\begin{array}{l}\text { Technology } \\
\text { Legacy }\end{array}$} & PC Banking & $\begin{array}{l}\text { Total experience in months of PC } \\
\text { banking as pre-Internet technology at } \\
\text { the end of } 2001\end{array}$ & $\begin{array}{l}\text { Survey and company } \\
\text { records }\end{array}$ \\
\hline & Telephone Banking & $\begin{array}{l}\text { Total experience in months of } \\
\text { telephone banking as pre-Internet } \\
\text { technology at the end of } 2001\end{array}$ & $\begin{array}{l}\text { Survey and company } \\
\text { records }\end{array}$ \\
\hline \multirow[t]{2}{*}{$\begin{array}{l}\text { Organizational } \\
\text { Legacy }\end{array}$} & Financial Control & $\begin{array}{l}\text { Extent of ownership concentration } \\
\text { and centralization (BankScope } \\
\text { Independence indicator) }\end{array}$ & $\begin{array}{l}\text { BankScope, } \\
\text { company records }\end{array}$ \\
\hline & $\begin{array}{l}\text { Operational control } \\
\text { (Spin-off) }\end{array}$ & $\begin{array}{l}\text { Dummy for spin-off versus traditional } \\
\text { incumbent operation }\end{array}$ & $\begin{array}{l}\text { Survey and company } \\
\text { records }\end{array}$ \\
\hline \multirow[t]{3}{*}{ Country Legacy } & $\begin{array}{l}\text { Product Market } \\
\text { Size }\end{array}$ & $\begin{array}{l}\text { Factor score of total assets, total } \\
\text { deposits, total number of banks, and } \\
\text { total number of bank branches in each } \\
\text { product market }\end{array}$ & $\begin{array}{l}\text { BankScope, } \\
\text { National Banking } \\
\text { Associations }\end{array}$ \\
\hline & Bank Coverage & $\begin{array}{l}\text { Number of banks per } 1 \text { million } \\
\text { population in each country }\end{array}$ & $\begin{array}{l}\text { Euromonitor, } \\
\text { National Banking } \\
\text { Associations }\end{array}$ \\
\hline & Internet Penetration & $\begin{array}{l}\text { Internet usership per population in } \\
\text { each country }\end{array}$ & Euromonitor \\
\hline \multirow[t]{3}{*}{$\begin{array}{l}\text { Resource Legacy } \\
\text { (Controls) }\end{array}$} & Dominance & $\begin{array}{l}\text { Factor score of total assets, total } \\
\text { deposits, and profits }\end{array}$ & BankScope \\
\hline & Bricks \& Mortar & $\begin{array}{l}\text { Total number of bricks-and-mortar } \\
\text { bank branches }\end{array}$ & Company records \\
\hline & Customers & $\begin{array}{l}\text { Total number of personal banking } \\
\text { customers }\end{array}$ & $\begin{array}{l}\text { Survey and company } \\
\text { records }\end{array}$ \\
\hline
\end{tabular}

\section{Model}

We now present the model specification and estimation based on the conceptual framework in Figure 1, the hypotheses and the operationalized measures. We tested three models in all: the full model (denoted as Model 3) as well as two models which contain only partial aspects of legacy (Model 1 and Model 2). In particular, Model 1 explains the dependent variables market performance and radical innovation speed by the control variables resource legacy only. We then include successively the main aspects of legacy, i.e., technology legacy in 
Model 2. Finally, the fully specified Model 3 contains all elements of legacy, i.e., resource, technology and organizational and country legacy effects.

\section{Model Specification}

For each firm, we write the generic simultaneous regression equations (1) and (2) as follows:

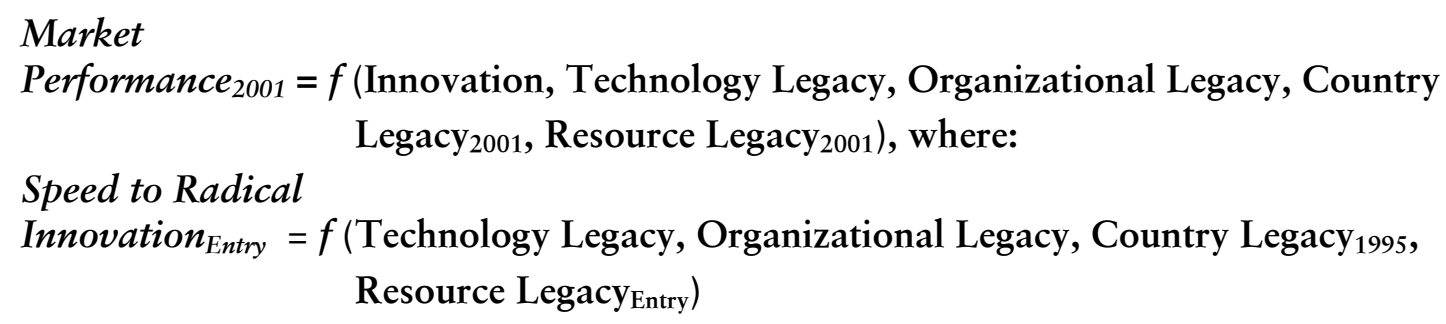

Equations (1) and (2) show how we sought to incorporate the longitudinal timing dimension in our model. Market performance in 2001 is depicted as a function of its resource legacy in 2001 and the embedded country legacy in 2001. Technology legacy and organizational legacy are independent of the longitudinal dimension as they were measured at the time of adopting the radical innovation. On the other hand, initial entry speed refers to the respective year of embracing the focal innovation which in turn is a function of banks' resource legacy at the year of entry. Nonetheless, the embedded country legacy refers to 1995, the year prior to any innovative activity in Internet banking throughout Europe.

We specify the complete model of simultaneous equations with the main regression (3) and the subsidiary regression (4) as follows:

Market

Performance $_{2001}=\beta_{0}+\beta_{1}$ (Speed to Radical Innovation $)_{\mathrm{i}}+\beta_{2}$ (Subsequent Innovation $)_{\mathrm{i}}$

$+\beta_{3}(\mathrm{PC} \text { Banking })_{\mathrm{i}}+\beta_{4}(\text { Telephone Banking })_{\mathrm{i}}+\beta_{5}(\text { Financial Control })_{\mathrm{i}}$

$+\beta_{6}(\text { Spin-Off })_{\mathrm{i}}+\beta_{7}(\text { Product Market Size } 2001)_{\mathrm{j}}$

$+\beta_{8}\left(\text { Bank Coverage }_{2001}\right)_{\mathrm{j}}+\beta_{9}\left(\text { Internet Penetration }_{2001}\right)_{\mathrm{j}}$

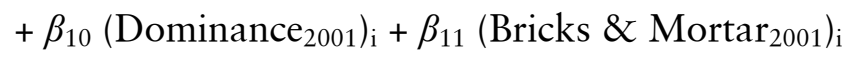

$+\beta_{12}(\text { Customers } 2001)_{\mathrm{i}}+\varepsilon_{\mathrm{i}}^{1}$

for $i=1$ to 123 firms and in country $j$, referring to the end of 2001, where simultaneously: 


\section{Speed to Radical}

Innovation $_{\text {Entry }}=\beta_{13}+\beta_{14}(\mathrm{PC} \text { Banking })_{\mathrm{i}}+\beta_{15}(\text { Telephone Banking })_{\mathrm{i}}$

$$
\begin{aligned}
& +\beta_{16}(\text { Financial Control })_{\mathrm{i}}+\beta_{17}(\text { Spin-Off })_{\mathrm{i}} \\
& +\beta_{18}\left(\text { Product Market Size }_{1995}\right)_{\mathrm{j}}+\beta_{19}\left(\text { Bank Coverage }_{1995}\right)_{\mathrm{j}} \\
& +\beta_{20}\left(\text { Internet Penetration }_{1995}\right)_{\mathrm{j}}+\beta_{21}\left(\text { Dominance }_{\text {Entry }}\right)_{\mathrm{i}}
\end{aligned}
$$

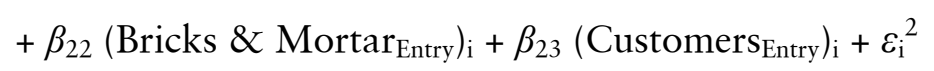

$$
\begin{aligned}
& \text { for } i=1 \text { to } 123 \text { firms and in country } j \text {, referring to each firm's entry year of } \\
& \text { adopting the focal innovation or to } 1995 \text { as a baseline for country controls. }
\end{aligned}
$$

\section{Model Estimation}

In order to test the hypotheses derived in section 2, we simultaneously estimate the systems of two equations using a three-stage least squares (3SLS) analysis (Zellner and Theil 1962; Greene 2003). This method is appropriate because speed to radical innovation is an endogenous variable, i.e., a dependent variable in equations (1) and (3) and an independent variable in equations (2) and (4). For this reason, ordinary least squares (OLS) cannot be applied to estimate the regression coefficients of our proposed model. Our use of 3SLS analysis is consistent with similar papers in marketing (Han et al. 1998).

\section{Results and Discussion}

\section{Descriptive Results}

Before addressing the results of our hypotheses testing in this section, we start by illustrating the descriptive nature of the empirical data collected from our sample of 123 European banks. Table 6 reveals the means, ranges and standard deviations of the variables of interest by firm and Table 7 shows their correlations. Due to the confidentiality of some data, e.g., customer numbers, we obtain a reduced but complete set of 111 banks containing all variables specified in the full model. The table of correlations shows that most variables of interest are related to one another with a very high level of significance. 
Table 6: Descriptive Statistics by Firm

\begin{tabular}{|c|c|c|c|c|c|}
\hline Variable & $\mathbf{N}$ & Minimum & Maximum & Mean & $\begin{array}{l}\text { Standard } \\
\text { Deviation }\end{array}$ \\
\hline Market Performance ${ }^{a}$ & 116 & 270 & $2,672,000$ & 303,740 & 466,371 \\
\hline Radical Innovation Speed & 123 & 2 & 71 & 35.02 & 16.66 \\
\hline Subsequent Innovation & 123 & 0 & 4 & 1.10 & 1.27 \\
\hline Dominance (Entry) ${ }^{c}$ & 123 & -0.58 & 5.31 & 0 & 1 \\
\hline Bricks \& Mortar (Entry) & 123 & 1 & 14,500 & 536 & 1,593 \\
\hline Customers (Entry) & 112 & 0 & $26,000,000$ & $1,786,527$ & $3,453,025$ \\
\hline PC Banking & 123 & 0 & 254 & 82.30 & 79.11 \\
\hline Telephone Banking & 123 & 0 & 234 & 80.36 & 52.28 \\
\hline Financial Control & 123 & 1 & 9 & 4.04 & 2.96 \\
\hline Operat. Control (Spin-off) & 123 & 0 & 1 & 0.18 & 0.38 \\
\hline Valid N (listwise) & 111 & & & & \\
\hline
\end{tabular}

${ }^{a}$ Measured by number of registered Internet banking customers (before log transformation)

${ }^{b}$ Measured by months of Internet banking experience as of 31 December 2001

${ }^{c}$ Factor score of total assets, deposits and profits at entry year of radical innovation 
Table 7: Correlations

\begin{tabular}{|c|c|c|c|c|c|c|c|c|c|c|}
\hline & $\begin{array}{l}\text { Market } \\
\text { Perfor- } \\
\text { mance }\end{array}$ & $\begin{array}{l}\text { Radical } \\
\text { Innovation } \\
\text { Speed }\end{array}$ & $\begin{array}{l}\text { Subsequent } \\
\text { Innovation }\end{array}$ & $\begin{array}{c}\text { Dominance } \\
\text { (Entry) }\end{array}$ & $\begin{array}{c}\text { Bricks \& } \\
\text { Mortar } \\
\text { (Entry) }\end{array}$ & $\begin{array}{l}\text { Customers } \\
\text { (Entry) }\end{array}$ & $\begin{array}{c}\text { PC } \\
\text { Banking }\end{array}$ & $\begin{array}{c}\text { Tele- } \\
\text { phone } \\
\text { Banking }\end{array}$ & $\begin{array}{c}\text { Financial } \\
\text { Control }\end{array}$ & $\begin{array}{l}\text { Operat. } \\
\text { Control }\end{array}$ \\
\hline Market Performance & 1.00 & & & & & & & & & \\
\hline Subsequent Innovation & $0.44^{* * *}$ & $0.38^{* * *}$ & 1.00 & & & & & & & \\
\hline Dominance (Entry) & $0.45^{* * *}$ & 0.05 & 0.13 & 1.00 & & & & & & \\
\hline Customers (Entry) & $0.56^{* * *}$ & $0.21 * *$ & 0.15 & $0.56 * * *$ & $0.53 * * *$ & 1.00 & & & & \\
\hline PC Banking & 0.02 & $0.32^{* * *}$ & $0.15 *$ & $0.25 * * *$ & $0.36 * * *$ & $0.26 * * *$ & 1.00 & & & \\
\hline Telephone Banking & $0.19 * *$ & $0.36^{* * *}$ & $0.35 * *$ & 0.13 & 0.10 & $0.21 \%$ & $0.20 * *$ & 1.00 & & \\
\hline Financial Control & $0.23 * *$ & $0.42 * * *$ & $0.23 * *$ & $0.29 \div \div$ & $0.17^{*}$ & $0.33 * * *$ & $0.31^{* * *}$ & $0.28^{* * *}$ & 1.00 & \\
\hline
\end{tabular}




\section{Radical Innovation Adoption}

Figure 5 below shows the adoption curve of all 123 firms in the sample across six countries embracing the focal innovation of Internet banking between January 1996 and December 2001. The adoption pattern follows the standard S-shape diffusion of innovation curve ( $c f$. Foster 1986, Rogers 1995) which also indicates that our sampling procedures were correct. Furthermore, the decreasing rate of adoption towards 2001 underlines the appropriate timing horizon of this study. At the end of 2001, most market players had indeed embraced the innovation of Internet banking. We would argue that only at that point of sustained decreasing adoption rates is it appropriate to look backwards and analyze the entire phenomenon from inception. Most attempts of earlier studies would have probably lacked a similar degree of completeness and comprehensiveness in the data.

Figure 5: Adoption Curve of Internet Banking in Europe $(n=123)$

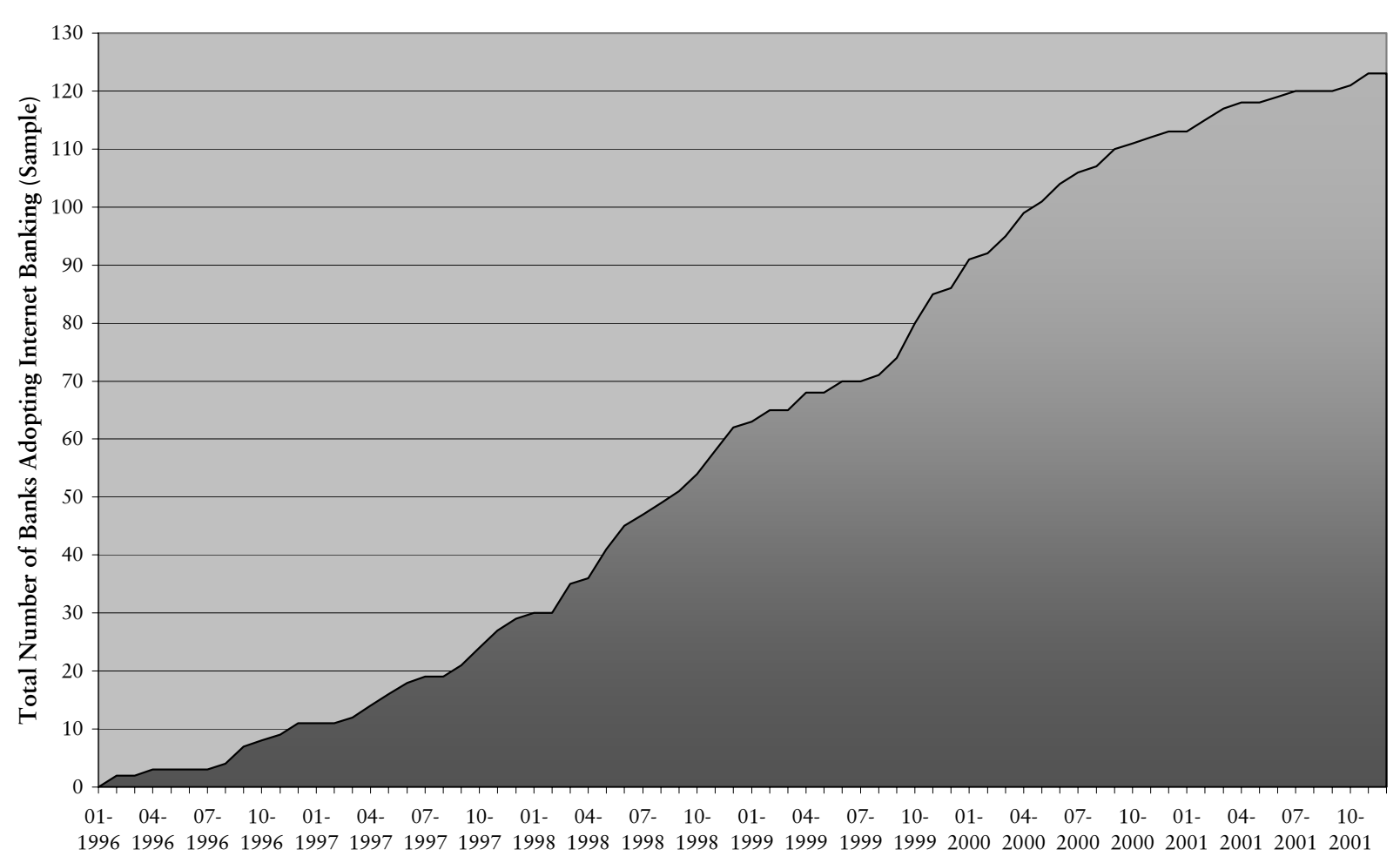

A curious anomaly can also be observed at the time of the millennium changeover, which could be termed the "Y2K effect". The adoption rate exhibits a decline prior to the end of 1999 and sharply increases again in early 2000. In reality, some banks with Internet operations due to start in the middle or in late 1999 were likely to postpone their launch until the new millennium in order to avoid subsequent $\mathrm{Y} 2 \mathrm{~K}$ changeover problems. A further 
advantage of a later entry in the first half of 2000 could have been a potentially more advanced platform of banking technology.

While Figure 5 represents the aggregate S-shaped adoption curve for the total of 123 sampled firms, the underlying adoption patterns differ considerably when analyzed across countries. Figure 6 below illustrates such a visual comparison for all six countries in the sample. The displayed adoption curves are directly comparable because of identical definition and scale of both axes ${ }^{14}$. The late adoption start of Denmark, for example, is clearly visible in comparison to its Scandinavian neighbors Finland and Sweden. The curves of the latter countries are relatively flat and characterized by an early adoption, rapidly encompassing the total market. Once virtually all banks in the highly concentrated Finnish and Swedish markets have entered, their adoption curves remain fairly stable.

14 The $y$-axis represents the cumulative number of firms having adopted Internet banking in each country market ( 0 to 45 ) and the $x$-axis represents the time frame (January 1996 to December 2001). 
Figure 6: Adoption Curves of Internet Banking by Country

GERMANY (n=42)

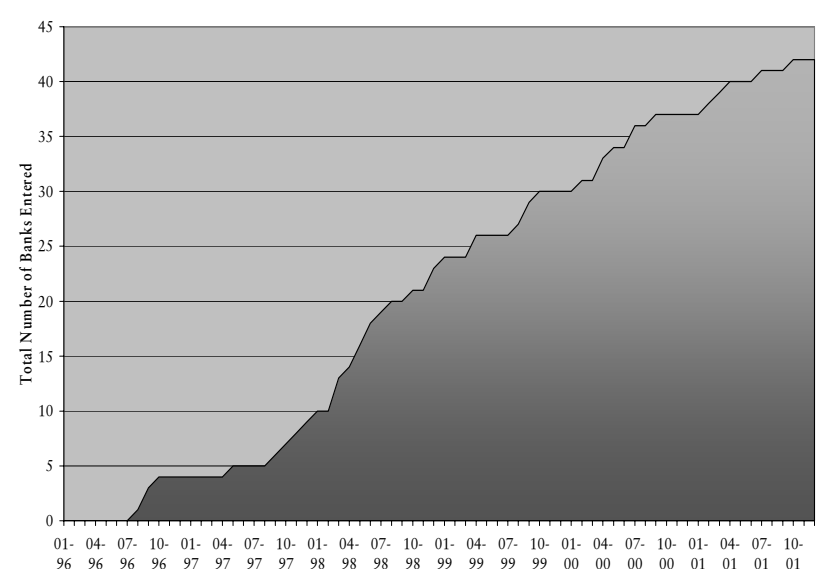

UNITED KINGDOM $(n=25)$

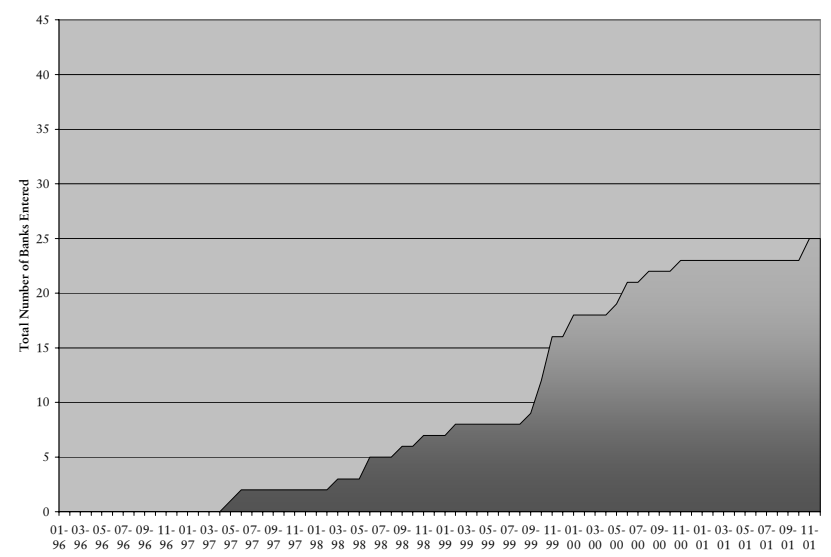

SWEDEN $(n=10)$

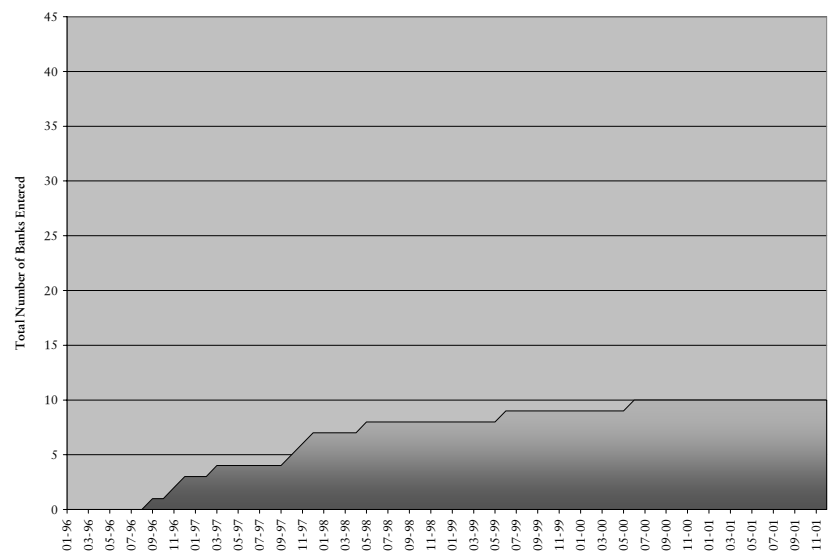

DENMARK $(n=22)$

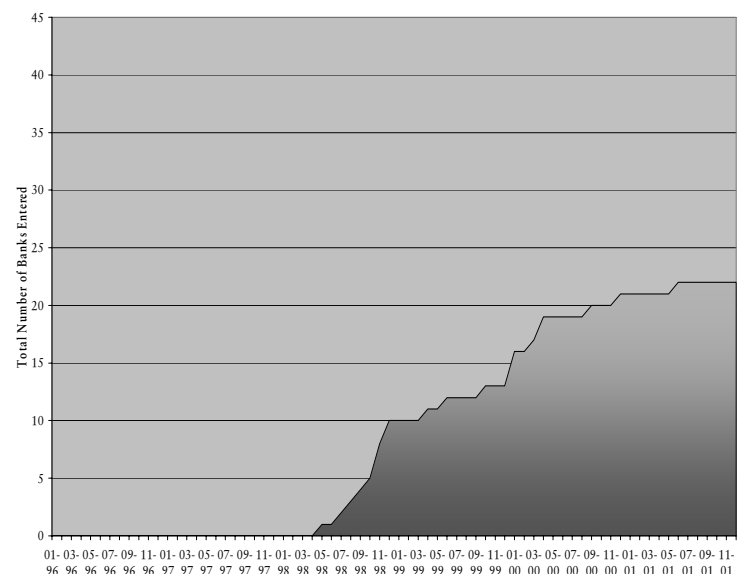

FRANCE ( $n=18)$

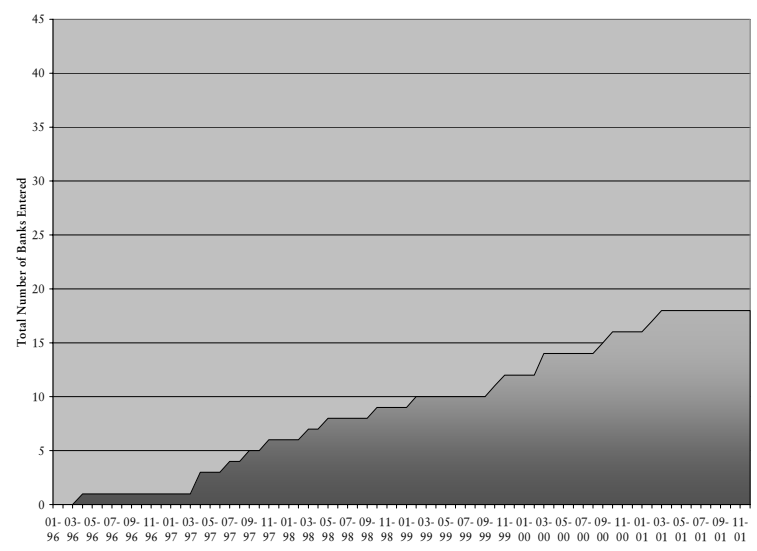

FINLAND ( $n=6)$

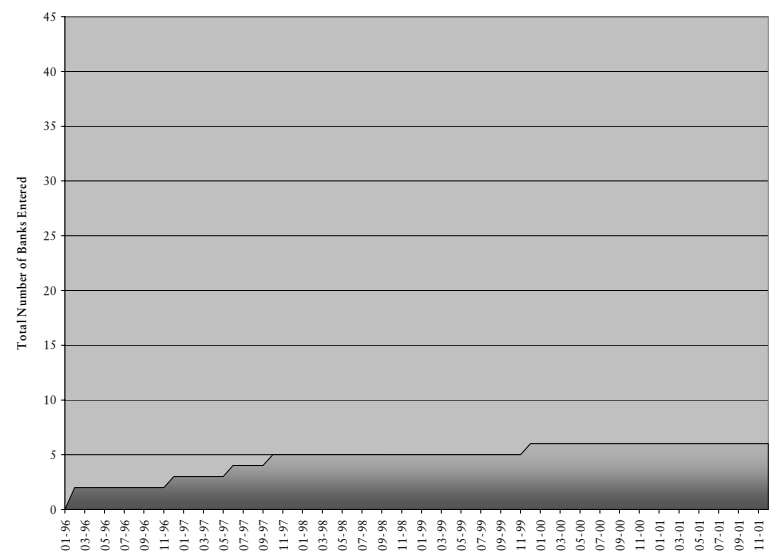




\section{Country Take-Off}

The curve for the United Kingdom, for example, illustrates a pattern of multiple entry waves after a relatively late start, especially for a country with a high economic significance of the banking sector. This pattern could be compared to the adopter categorization of innovators, early adopters, early/late majority and laggards on the basis of their innovativeness (Rogers 1995). One could also argue that the point of Internet banking "take-off" ( $c f$. Golder and Tellis 1997; Tellis, Stremersch and Yin 2003) in the United Kingdom occurred only with the third wave ${ }^{15}$. On the other hand, the first but comparatively late entry wave could be interpreted as point of take-off in the case of Denmark ${ }^{16}$. Based on the adoption curve in Germany, Internet banking take-off seemingly started with the second wave and afterwards continued at a fairly steady rate ${ }^{17}$. Like Germany with her prior Btx (Bildschirmtext) system, France represents another country with a strong legacy in the pre-Internet network Minitel. With the exception of one pioneering French bank for a sustained one-year period, the subsequent adoption pattern in France is comparatively linear. It could be argued that the strong technology legacy of Minitel in France and Btx in Germany may account for the relatively stable, linear pattern due to incumbents' greater awareness of pre-Internet direct banking solutions. The ultimate adoption timing by these banks may have been induced by internal organizational considerations rather than externally driven competitive dynamics. In the United Kingdom, however, a country with virtually no existence of prior (PC) direct banking legacy, the competitive dynamics in the market coupled with uncertainty could well have created a "herding" effect (e.g., see Camerer 1988; Choi and Kim 1996; Schelling 1960) with one group of banks merely following the moves of an earlier group of adopters. The fundamental group market dynamics would explain the disruptive patterns in the British adoption curve. Overall, the six charts in Figure 6 emphasize the underlying heterogeneity of different country characteristics that lead to a variety of adoption patterns within each market.

\section{Speed to Radical Innovation}

Furthermore, Figure 7 reveals the country means of speed to radical innovation, as measured by months of Internet banking experience as of December 2001. As such, the higher the bar chart, the more cumulative experience in the focal innovation, the faster the entry

\footnotetext{
1514 British banks entered during the 12-month period from September 1999 to August 2000 representing $56 \%$ of all sampled banks in the United Kingdom.

1610 Danish banks entered during the 8-month period from May to December 1998 representing about $45 \%$ of all sampled banks in the Denmark.

${ }^{17} 15$ German banks entered during the 12-month period from September 1997 to August 1998 representing about $36 \%$ of all sampled banks in the Germany.
} 
speed. The chart shows Finland and Sweden as the pioneering countries in Internet banking, whereas the United Kingdom together with Denmark remain the adoption laggards among our six sampled countries. Overall, the figure also shows sufficient cross-country variance based on our selection of six European countries and thus provides further evidence that our sample was well selected both within and across countries.

Figure 7: “Speed to Radical Innovation” Country Means ( $n=123)$

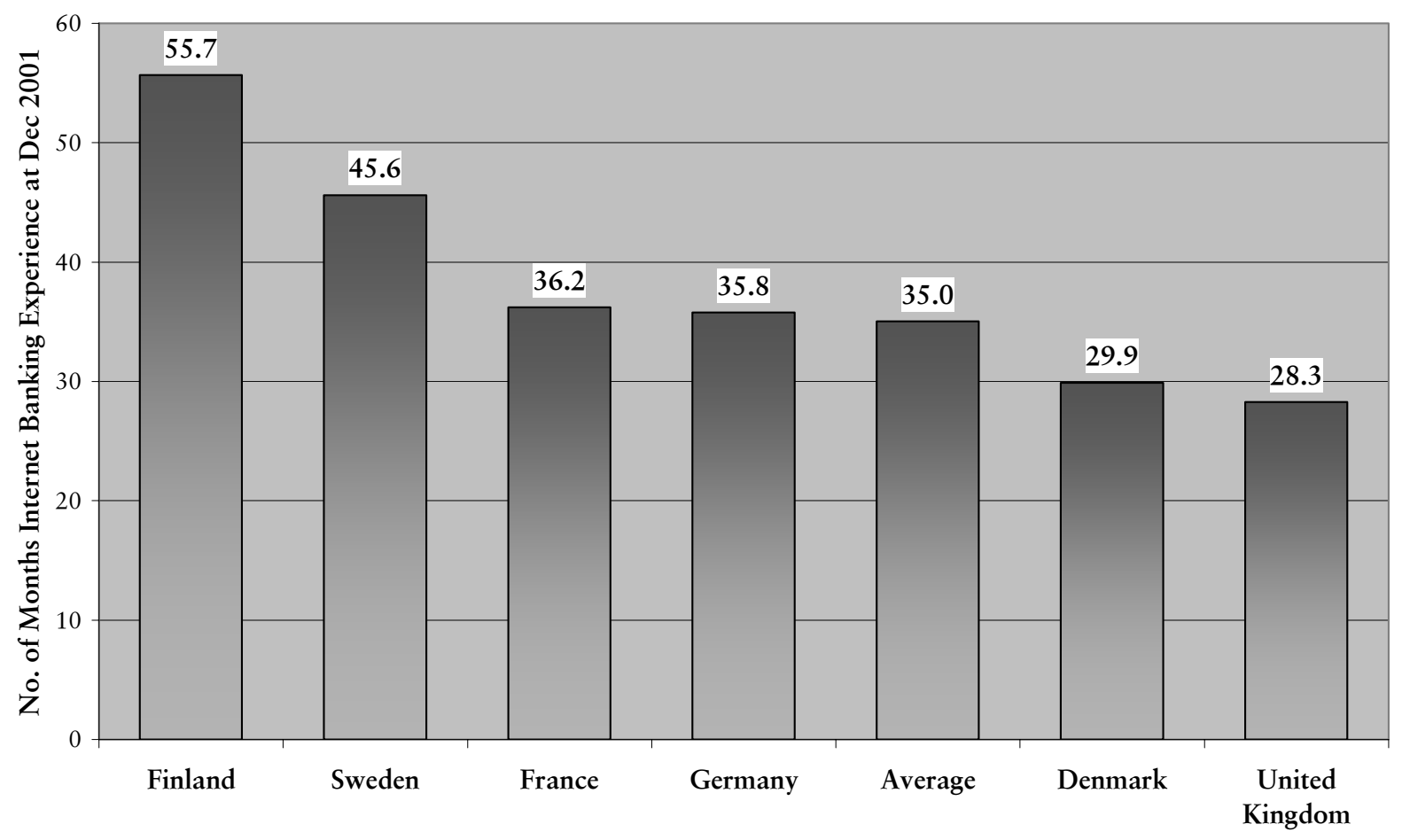




\section{Three-Stage Least Squares Results}

Tables 8 and 9 present the 3SLS estimation results of the models' simultaneous equations explaining speed to radical innovation and market performance respectively. Three outliers whose standard errors of the regression residuals exceeded 2.5 standard deviations were eliminated from the sample. Overall, we show in the progressive legacy models that all aspects of legacy are needed to explain the dependent variables. Model 1 contains only the controlling element of resource legacy while Model 2 contains resource and technology legacy. The complete Model 3 includes the former legacies plus organizational legacy and country legacy variables. As shown in Tables 8 and 9, subset Models 1 and 2 with partial legacy aspects are inferior to the complete Model 3 in explaining the dependent variables. This is demonstrated by the consistently increasing $\mathrm{R}^{2}$ values ${ }^{18}$ per simultaneous regression equation (by Model 1-3: 0.191 to 0.316 to 0.447 for speed to radical innovation and 0.576 to 0.659 to 0.676 for market performance). In the following sections, we present the results of the hypotheses testing and shall refer to the complete Model 3 in unless noted otherwise.

${ }^{18}$ As we are estimating two regression equations simultaneously via 3SLS analysis due to endogeneity of speed to radical innovation, the shown $\mathrm{R}^{2}$ values should be interpreted as "pseudo- $\mathrm{R}^{2} \mathrm{~s}$ ". 
Table 8: 3SLS Model Estimation Results for Market Performance

Effect on Market Performance (e-Customer Adoption)

\begin{tabular}{|c|c|c|c|c|}
\hline Category & Independent Variable & Model $1^{\mathrm{a}}$ & Model $2^{\mathrm{a}}$ & Model $3^{a}$ \\
\hline Innovation & $\begin{array}{l}\text { Radical Innovation Speed } \\
\text { Subsequent Innovation }\end{array}$ & $\begin{array}{l}0.009 \\
0.172 * * *\end{array}$ & $\begin{array}{l}0.018 * * \\
0.168 * * *\end{array}$ & $\begin{array}{l}0.015 * \\
0.141 * * *\end{array}$ \\
\hline $\begin{array}{l}\text { Resource } \\
\text { Legacy }\end{array}$ & $\begin{array}{l}\text { Dominance (2001) } \\
\text { Bricks \& Mortar (2001) } \\
\text { Customers (2001) }\end{array}$ & $\begin{array}{l}0.091 \\
6.95 \times 10^{-5 *} \\
4.78 \times 10^{-8 * *}\end{array}$ & $\begin{array}{l}0.103 * \\
9.88 \times 10^{-5 * *} \\
2.94 \times 10^{-8}\end{array}$ & $\begin{array}{l}0.097 * \\
9.15 \times 10^{-5 * *} \\
3.17 \times 10^{-8 *}\end{array}$ \\
\hline $\begin{array}{l}\text { Technology } \\
\text { Legacy }\end{array}$ & $\begin{array}{l}\text { PC Banking } \\
\text { Telephone Banking }\end{array}$ & & $\begin{array}{l}-0.003 * * * \\
0.003 * *\end{array}$ & $\begin{array}{l}-0.002 * * \\
0.004 * * *\end{array}$ \\
\hline $\begin{array}{c}\text { Organizational } \\
\text { Legacy }\end{array}$ & $\begin{array}{l}\text { Financial Control } \\
\text { Operational Control (Spin-off) }\end{array}$ & & & $\begin{array}{l}0.025 \\
0.344 *\end{array}$ \\
\hline \multirow[t]{6}{*}{ Country Legacy } & $\begin{array}{l}\text { Product Market Size (2001) } \\
\text { Bank Coverage (2001) } \\
\text { Internet Penetration (2001) }\end{array}$ & $\begin{array}{l}0.175 * \\
-0.015 * * * \\
0.017\end{array}$ & $\begin{array}{l}0.187 * * \\
-0.014 * * * \\
-0.507\end{array}$ & $\begin{array}{l}0.251 * * * \\
-0.015 * * * \\
-0.154\end{array}$ \\
\hline & Constant & $4.766 * * *$ & $4.665 * * *$ & $4.38 * * *$ \\
\hline & " $\mathrm{R}^{2} "$ & 0.576 & 0.659 & 0.676 \\
\hline & Wald $\chi 2$ Statistic & 133.72 & 196.68 & 214.20 \\
\hline & $p$-value & $<0.0001$ & $<0.0001$ & $<0.0001$ \\
\hline & $\mathrm{n}$ & 111 & 111 & 108 \\
\hline
\end{tabular}

$$
\begin{array}{cll}
\text { Note: } & * * & p<0.01 \\
& * * & p<0.05 \\
& * & p<0.10 \\
& \text { n.s. } & p>0.10
\end{array}
$$

${ }^{\text {a }}$ Non-standardized coefficients 
Table 9: 3SLS Model Estimation Results for Speed to Radical Innovation

Effect on Radical Innovation Speed (Internet Banking Entry)

\begin{tabular}{|c|c|c|c|c|}
\hline Category & Independent Variable & Model $1^{\mathrm{a}}$ & Model $2^{\mathrm{a}}$ & Model $3^{a}$ \\
\hline $\begin{array}{l}\text { Resource } \\
\text { Legacy }\end{array}$ & $\begin{array}{l}\text { Dominance (Entry) } \\
\text { Bricks \& Mortar (Entry) } \\
\text { Customers (Entry) }\end{array}$ & $\begin{array}{l}-1.543 \\
6.8 \times 10^{-4} \\
1.5 \times 10^{-6 * * *}\end{array}$ & $\begin{array}{l}-2.127 \\
2.32 \times 10^{-4} \\
9.48 \times 10^{-7} *\end{array}$ & $\begin{array}{l}-2.525 * \\
3.63 \times 10^{-4} \\
6.73 \times 10^{-7}\end{array}$ \\
\hline $\begin{array}{l}\text { Technology } \\
\text { Legacy }\end{array}$ & $\begin{array}{l}\text { PC Banking } \\
\text { Telephone Banking }\end{array}$ & & $\begin{array}{l}0.043 * * \\
0.101 * * *\end{array}$ & $\begin{array}{l}0.483 * * \\
0.123 * * *\end{array}$ \\
\hline $\begin{array}{c}\text { Organizational } \\
\text { Legacy }\end{array}$ & $\begin{array}{l}\text { Financial Control } \\
\text { Operational Control (Spin-off) }\end{array}$ & & & $\begin{array}{l}1.861 * * * \\
11.475 * * *\end{array}$ \\
\hline \multirow[t]{6}{*}{ Country Legacy } & $\begin{array}{l}\text { Prod. Market Size (1995) } \\
\text { Bank Coverage (1995) } \\
\text { Internet Penetration (1995) }\end{array}$ & $\begin{array}{l}4.424 * * \\
0.027 \\
187.81 * * *\end{array}$ & $\begin{array}{l}4.416 * * \\
-0.037 \\
140.07 * * *\end{array}$ & $\begin{array}{l}5.74 * * * \\
-0.087 \\
128.12 * * *\end{array}$ \\
\hline & Constant & $23.193 * *$ & $17.206 * * *$ & $7.585 *$ \\
\hline & " $R^{2} "$ & 0.191 & 0.316 & 0.447 \\
\hline & Wald $\chi^{2}$ Statistic & 27.44 & 51.28 & 87.47 \\
\hline & $p$-value & 0.0001 & $<0.0001$ & $<0.0001$ \\
\hline & $\mathrm{n}$ & 111 & 111 & 108 \\
\hline
\end{tabular}

$$
\begin{array}{lll}
\text { Note: } & * * * & p<0.01 \\
& * * & p<0.05 \\
& * & p<0.10 \\
& \text { n.s. } & p>0.10
\end{array}
$$

${ }^{\text {a }}$ Non-standardized coefficients 


\section{Technology Legacy}

\section{Effect on Speed to Radical Innovation}

How do different technology legacies affect the swiftness of firms' Internet banking adoption? Hypothesis $\mathrm{H}_{1}$ suggests that firms with a greater extent of technology legacy are likely to adopt radical innovations faster. Our results reveal that the extent of pre-Internet direct banking experience has indeed a positive and highly significant impact on speed to Internet banking entry. This result suggests support for our argument that the prevalent negative view of legacies in the literature is likely to be overstated. Therefore, our findings add further emphasis to the focus on prior experience in radical technology shifts by King and Tucci $(2000,2002)$. Overall, the found effect holds for both complementary (telephone banking) and replacement (PC banking) technologies, although it is stronger for the latter $(\beta=$ 0.123 and $0.483, p<0.01$ and 0.05 respectively). The importance of including the technology legacy aspect in our model is also emphasized by the results. As such, explaining entry speed by controlling for resource legacy alone naturally represents a partial view, as the $\mathrm{R}^{2}$ value improves from 0.191 to 0.316 .

It is also important to emphasize the implicit link between technology legacy and the organizational legacy of being a spin-off (see next section for results). By definition, a spin-off operation in Internet banking has zero or practically zero technology legacy. Therefore, firms in this category should have the advantage of tabula rasa, as they are free from any prior direct banking legacies and should thus be able to move faster towards adopting the radical innovation ${ }^{19}$. On the other hand, more experience in earlier technologies could have created a legacy of related resources, especially human, and organizational routines (cf. Nelson and Winter 1982). The latter should facilitate the awareness of the focal innovation and thus improve speed to radical innovation, as can be demonstrated by the results in support of $\mathrm{H}_{1}$. This seeming contradiction is only resolved by including both aspects of firm legacy, the technology and the organizational component, in the fully specified model.

Further descriptive results on the similar impact of the two technology legacies on speed to radical innovation can be found in Figure 8. Performing a median split for the extent of technology legacy, we show an increase in the average speed to radical innovation with increasing technology legacy.

\footnotetext{
${ }^{19}$ In fact, $\mathrm{H}_{5}$ tests the organizational legacy of being a new player and is supported at $\mathrm{p}<0.01$, as we shall demonstrate in the following section.
} 
Figure 8: Average Speed to Radical Innovation by Extent of Technology Legacy

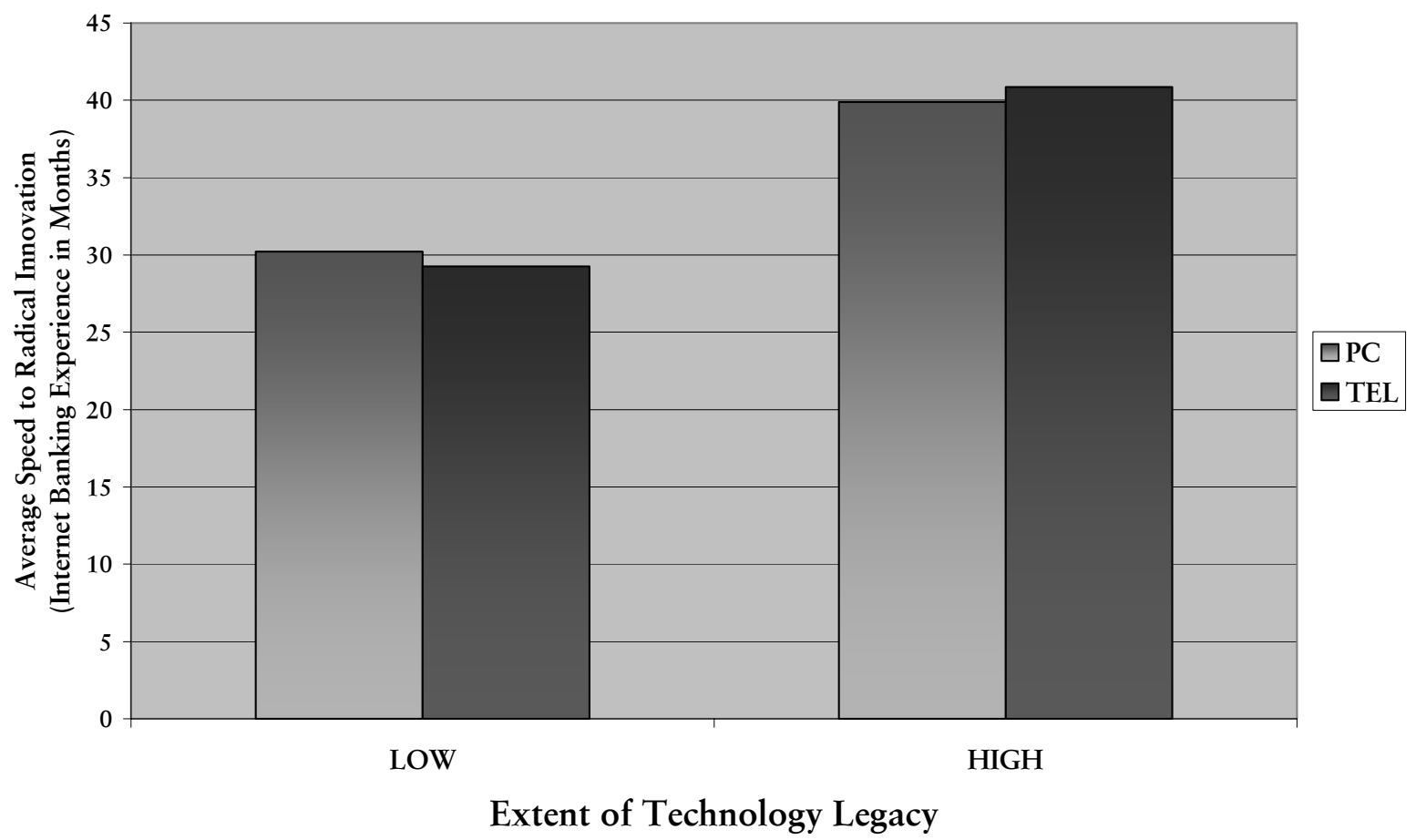

\section{Effect on Market Performance}

How do different technology legacies affect market performance in the longer term? Hypotheses $\mathrm{H}_{2 \mathrm{a}}$ and $\mathrm{H}_{2 \mathrm{~b}}$ argue that a greater extent of complementary technology legacy helps market performance whereas a replacement technology legacy hurts performance in the same manner. The model estimation coefficients support our initial belief that the extent of different technology legacies has indeed different customer cannibalization effects. Overall, PC banking has the expected negative and telephone banking the expected positive effect on market performance, both showing a high level of significance $(\beta=-0.002$ and $0.004, p<0.05$ and < 0.01 respectively). The estimation results clearly emphasize the importance of technology legacy as a separate dimension in our model. This can be seen when comparing subset Models 1 and 2 where technology legacy represented the added element in Model 2 (see Table 9).

Performing the same median split for technology legacy but applied to average market performance clearly illustrates the opposite effects of complementary versus replacement legacy (see Figure 9). As technology legacy increases, the average performance for the replacement technology PC banking falls. 
Figure 9: Average Market Performance by Extent of Technology Legacy

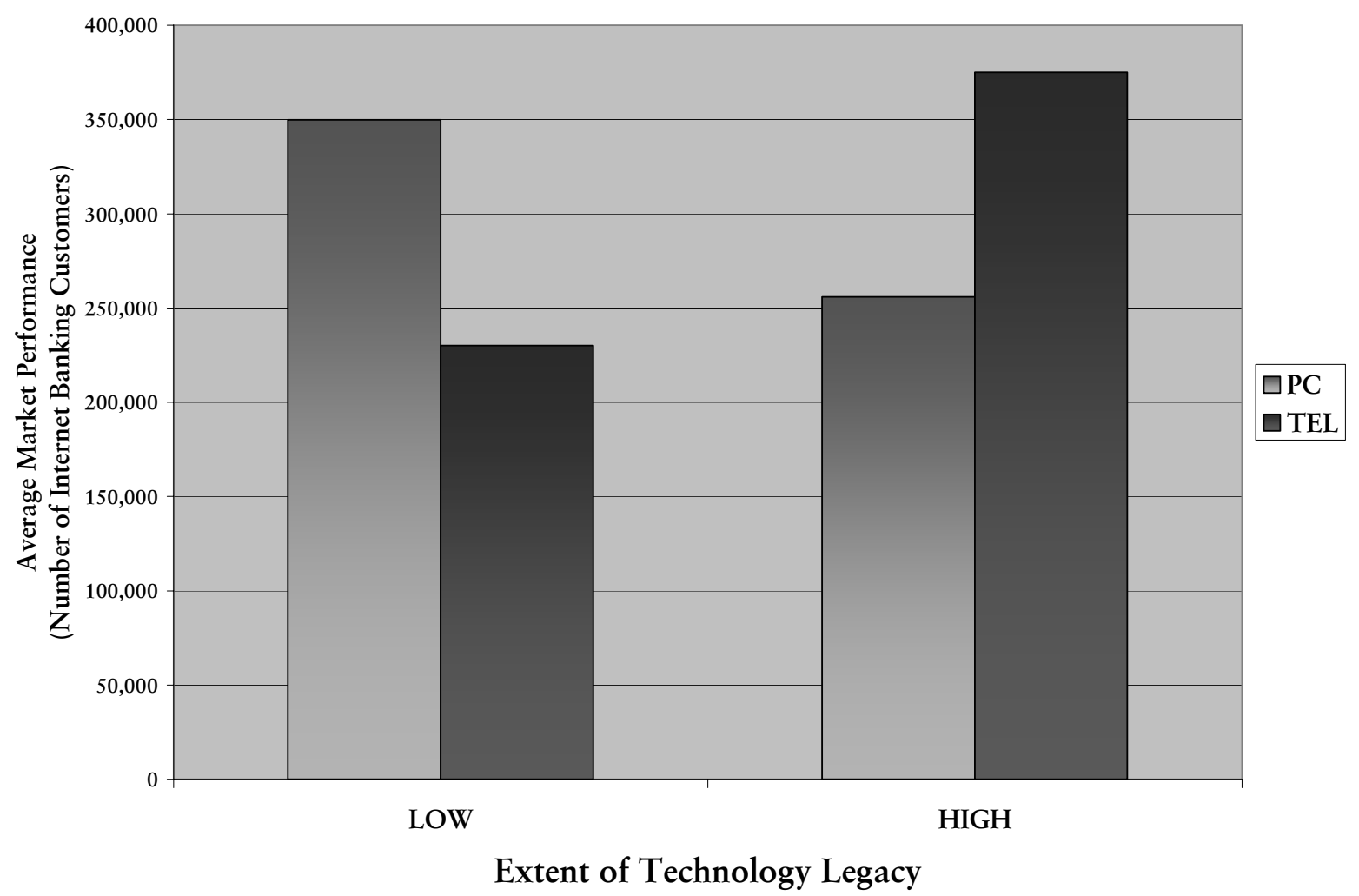

\section{Organizational Legacy}

\section{Effect on Speed to Radical Innovation}

How does firms' organizational legacy affect the speed of embracing a radical innovation? Hypothesis $\mathrm{H}_{3}$ suggests that firms with a lower degree of financial and operational control tend to adopt radical innovations faster. Our results provide support for $\mathrm{H}_{5}$ with both regression coefficients being positive ${ }^{20}$ and highly significant $(\beta=1.861$ and 11.475 respectively, $p<0.01$ ). Thus, low operational control, i.e., institutional independence from shareholders, equally seems to promote management independence by allowing for more flexibility in the strategic decision of when to embrace the focal innovation. We argued earlier that a dominant influence by firms' majority or sole shareholders would be unlikely to provide such organizational flexibility to management.

Our complete Model 3 suggests, for example, that a firm with a very low degree of financial control (i.e., a highly shareholder independent firm) would adopt the focal innovation of Internet banking almost 15 months earlier (on average) than a firm with high financial

\footnotetext{
${ }^{20}$ Since the variable was operationalized by the independence measure (indicating low control), a positive coefficient suggests faster speed to radical innovation.
} 
control $^{21}$. Similarly, across the entire sample, the mere fact of being a spin-off operation as a new entrant in the Internet banking area (not referring to direct banking in general) seems to help speed to radical innovation by entering (on average) almost 12 months earlier ${ }^{22}$. A further comparison of the full Model 3 with its two subsets reveals that the element of organizational legacy is just as important to explaining entry speed as the previous technology legacy. Accordingly, the $\mathrm{R}^{2}$ values surge from 0.316 to 0.447 with the organizational legacy dimension added to the full model. This is a further indication that all three aspects of firm legacy are required to adequately model speed to radical innovation.

Figure 10 presents the median split for the extent of operational control (spin-off operation versus a traditional incumbent) measured by average speed to radical innovation.

Figure 10: Average Speed to Radical Innovation by Extent of Organizational Legacy (Operational Control)

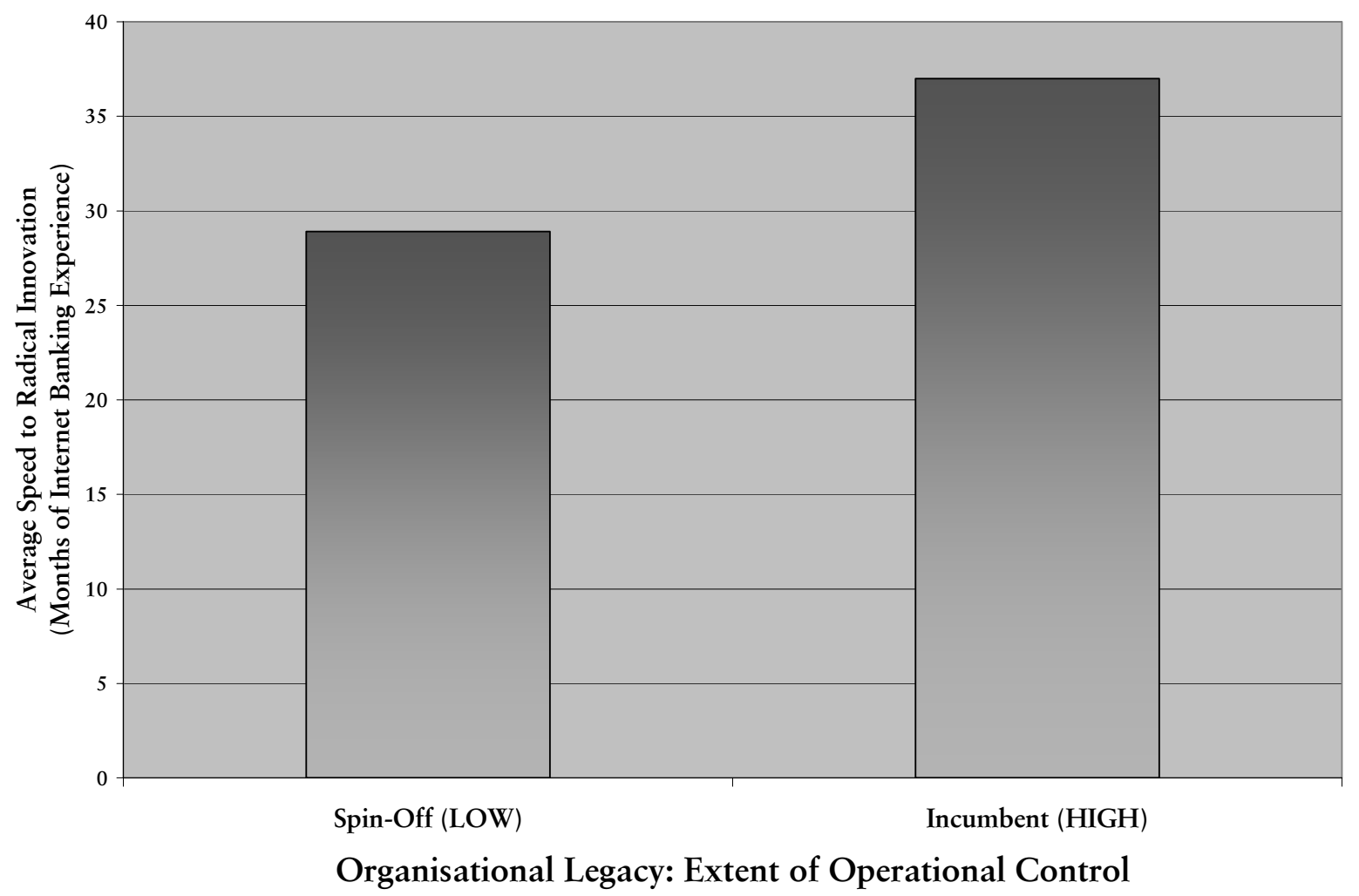

21 "Highly independent" refers to a scaled maximum value of 9 and "highly dependent" refers to a scaled minimum value of 1 for the independence indicator. Hence, the $\beta$ coefficient of $1.861 \times(9-1)=14.89$, or almost 15 months of Internet banking experience, as measured by the dependent variable.

22 The $\beta$ coefficient for the dummy variable spin-off player (11.475) can be translated directly in additional months of Internet banking experience, as measured by the dependent variable. 


\section{Effect on Market Performance}

$\mathrm{H}_{4}$ states that firms with a lower degree of financial and operational control are likely to perform better in the longer term. In contrast to $\mathrm{H}_{3}$ and the noted effect on radical innovation speed, organizational legacy does not appear to play an equally critical role in explaining market performance over time. We only find support for the spin-off dummy variable, indicating a positive and significant effect $(\beta=0.344, p<0.10)$. The independence indicator revealing the degree of financial control is not significant in the complete Model 3. As such, the more crucial question remains how to organize for radical innovation in the first instance rather than how to organize for longer term success. Indeed it is plausible with hindsight that both low and high financial control could promote market performance thus yielding the non-significant result for the regression coefficient $(\beta=0.025)$. Highly controlled firms, for example subsidiary entities or separate divisions within a larger banking group, could nonetheless benefit from their parents' three elements of dominance when trying to attract customers to the focal innovation ${ }^{23}$. As we argued earlier, banks with fewer financial controls should perform better because of institutional flexibility and consequently a greater degree of responsiveness to changing market conditions, which in turn could result in attracting more customers.

We now show again the median split for operational control but measured in terms of average market performance. Our descriptive results indicate only marginal difference between spin-offs and traditional incumbents with respect to average market performance.

${ }^{23}$ For example, several new Internet banks in the United Kingdom may be highly dependent according to our measure but nonetheless market themselves quite successfully as "X - the new Internet bank of Y Group". 


\section{Figure 11: Average Market Performance by Extent of Organizational Legacy (Operational Control)}

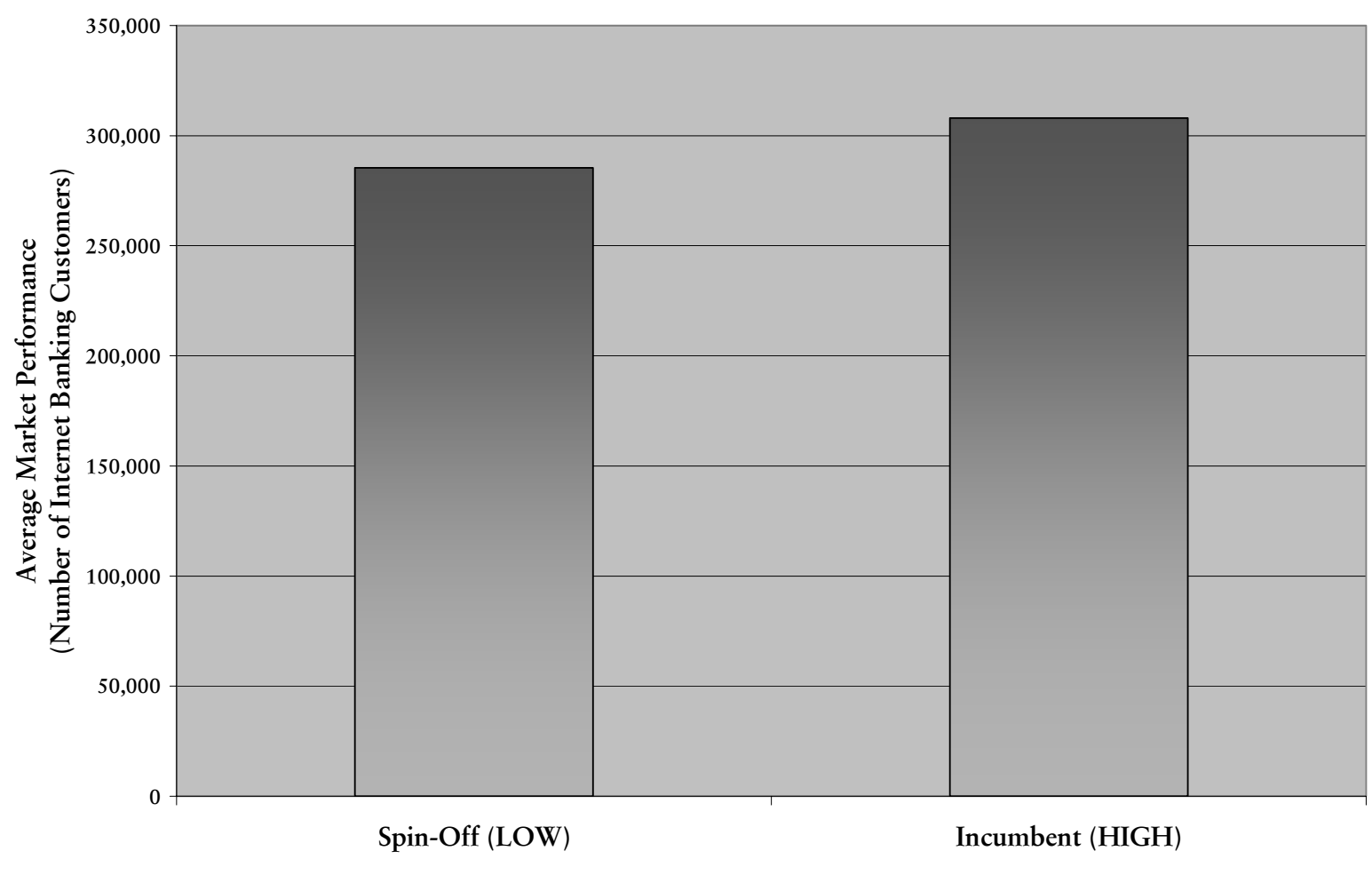

Organisational Legacy: Extent of Operational Control

\section{Country Legacy}

\section{Effect on Speed to Radical Innovation}

Do country differences matter and what is the impact of structural and competitive variations across countries on speed to radical innovation? Hypothesis $\mathrm{H}_{5}$ argues that firms operating in larger product markets by country tend to embrace the focal innovation of Internet banking faster. Thus, the larger the underlying product market for banking services, the greater the opportunity for subsequent diffusion of the focal innovation within each country. We find support for this hypothesis with a positive and highly significant coefficient for the size of the banking market in 1995, denoting the year before the first European bank adopted the focal innovation $(\beta=5.74, p<0.01)$.

The descriptive results in Figure 12 reveal the median split for the extent of country legacy related to product market size. 
Figure 12: Average Speed to Radical Innovation by Extent of Country Legacy (Product Market Size)

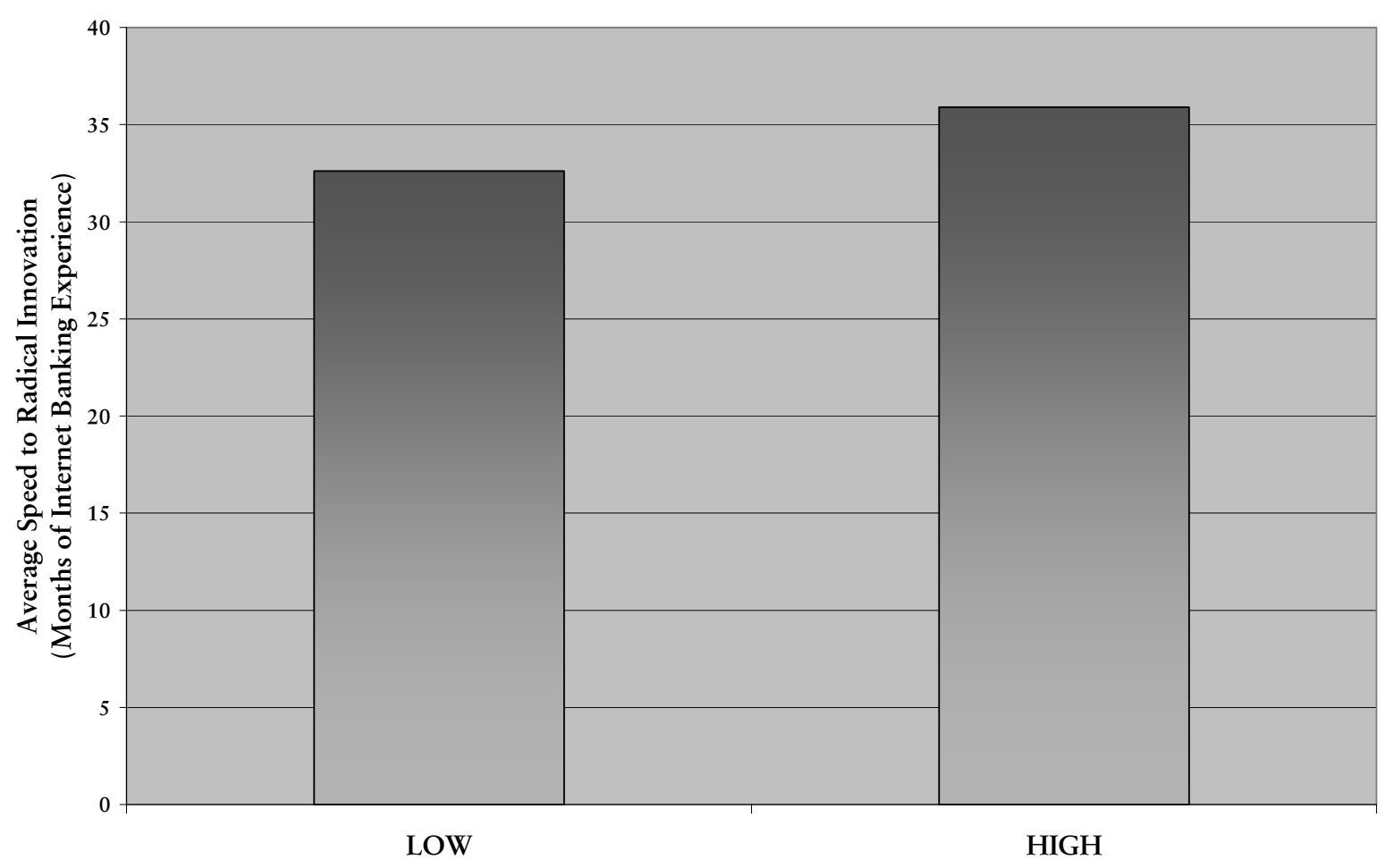

Country Legacy: Extent of Product Market Size

The other country legacy with an important effect on speed to radical innovation is each country's level of Internet penetration in 1995, as this metric clearly relates to a degree of market readiness for the focal innovation. With Internet proliferation representing a crucial but obvious prerequisite to the rapid adoption of our focal innovation, we therefore did not pose a separate country legacy hypothesis suggesting a positive effect. As expected, however, the regression coefficient for Internet penetration in 1995 in indeed positive and highly significant $(\beta=128.12, p<0.01)$. In particular, this aspect of country legacy accounts for the remarkably swift adoption patterns in Finland and Sweden where the highest penetration rates could be found in 1995. Figure 13 below exhibits the comparative Internet penetration levels in 1995 and 2001 by country. The relative differences between penetration rates were considerably higher in 1995 than in 2001. Moreover, the Scandinavian countries show an apparent convergence in their penetration levels by 2001 . 
Figure 13: Internet Penetration by Country: 1995 vs. $2001^{24}$

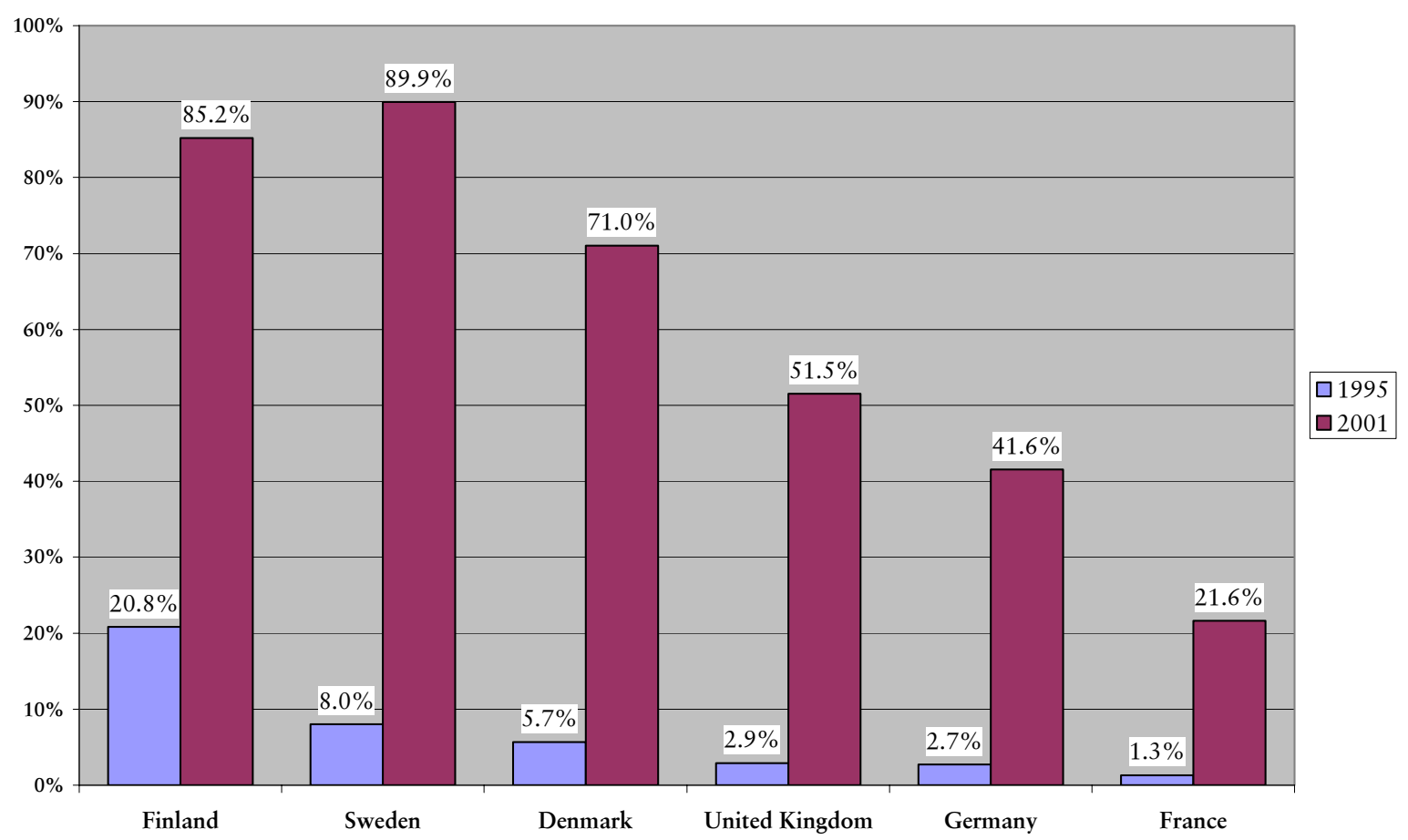

\section{Effect on Market Performance}

Overall, country differences do seem to matter, both in relation to speed to radical innovation and market performance, as the highly significant coefficients generally show for both dependent variables in Models 1 to 3. With respect to market performance, hypothesis $\mathrm{H}_{6}$ suggests that firms should perform worse if the number of market players per population is high. If any given population of potential Internet banking users is being chased by many banking players within one country, then the resulting market performance in terms of Internet banking customers should be lower. In other words, the lower the bank coverage per country, the higher the incentive for customers to adopt Internet banking as an alternative channel to branch banking. This applies particularly to the cases of Finland, Sweden and the United Kingdom. Our results indicate strong support for this hypothesis with a negative and highly significant coefficient $(\beta=-0.015, p<0.01)$.

The descriptive results in Figure 14 reveal the median split for the extent of country legacy related to bank coverage which confirms the negative effect of market concentration on performance as obtained by the 3SLS models.

\footnotetext{
${ }^{24}$ Source: Euromonitor
} 
Figure 14: Average Market Performance by Extent of Country Legacy (Bank Coverage)

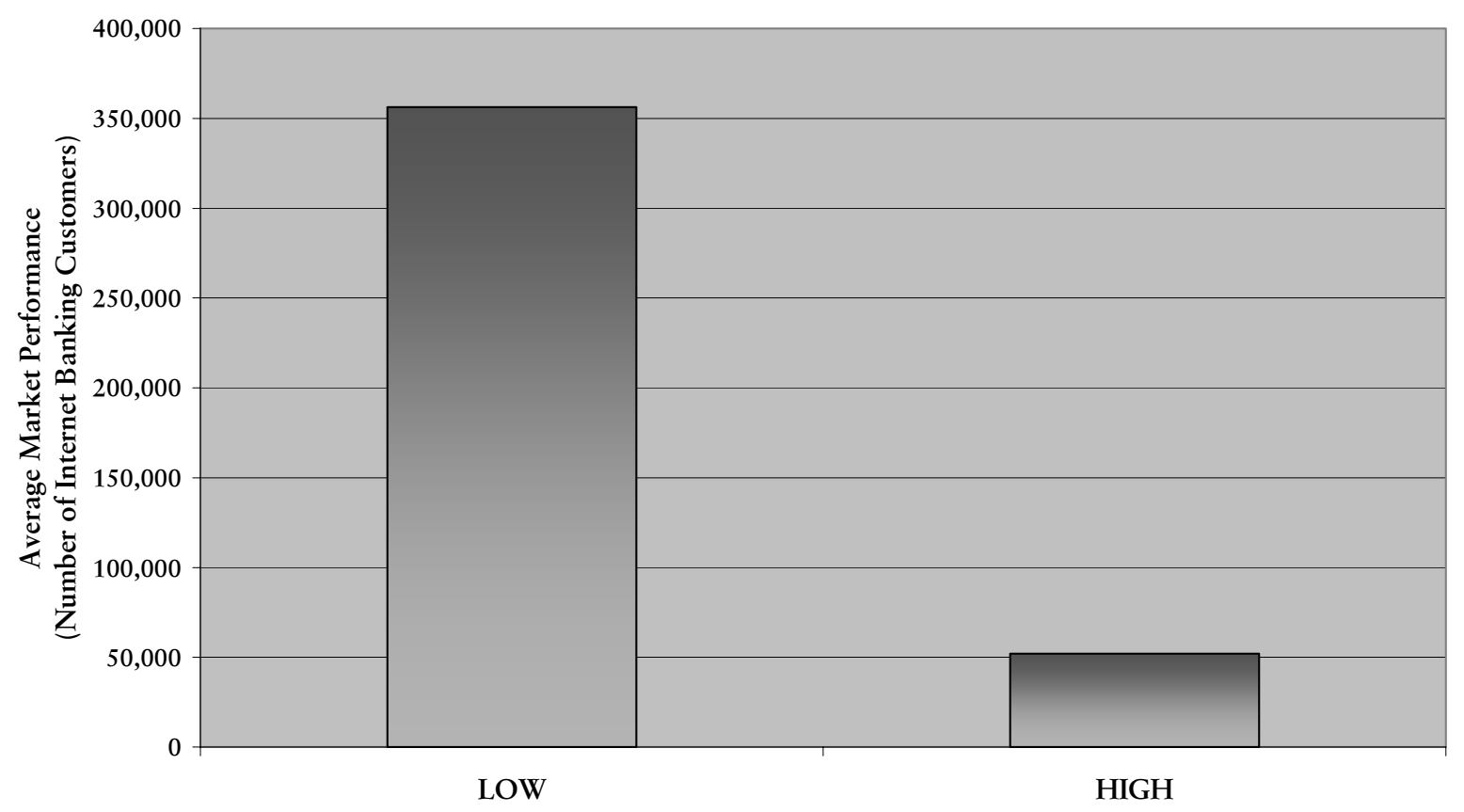

Country Legacy: Extent of Bank Coverage

Whereas Internet penetration by country was one of the main drivers determining entry speed to radical innovation, this metric does not play a similarly crucial role with regards to market performance. The underlying reason could be found in countries' increasing convergence of Internet penetration levels by the end of 2001 as opposed to 1995 (see Figure 13). In most cases, Internet penetration merely needed to reach a critical threshold for Internet banking to induce initial take-off by country. Hence, our model demonstrates that subsequent market performance is more likely to be influenced by individual firm-level characteristics than general variations across countries.

\section{Implications and Conclusions}

\section{Managerial Implications}

How can managers benefit from our research? We initially argued that the overly negative view of legacies prevailing in the literature could potentially lead to erroneous managerial practice. To counter this view, we have shown that experience with a prior related technology, for example, can help firms to embrace radical innovations faster. Subsequent performance, however, depends on the nature of the previous technology, whether rendering the focal innovation obsolete or merely complementing it. 


\section{Lessons for Managers}

This research sends a set of clear messages to managers: First, experience with the legacy of previous technologies helps raising awareness for the focal innovation and creates the necessary organizational routines and firm-specific capabilities to innovate faster when it really matters. Second, it is not imperative to always be a pioneer in a new technology. Even if radical innovations are embraced at a later stage, subsequent performance can be superior, provided that sufficient resources are available to suitably deliver the innovation to the customer. Therefore, dominance tends to hurt initially but prevails in the end. Third, managers should regard subsequent innovation efforts as investments in real options. That is, subject to resource dominance, it helps to have an initial stake in as many post-radical technologies as possible, hoping that at least one of them will eventually take off. Overall, we found little indication of channel cannibalization among the radical and subsequent innovations. Instead, customers clearly value the convenience of free choice from multiple channels as well as owning the channel themselves ${ }^{25}$.

\section{Internet Banking Failures}

The finding that dominance prevails in the end should come as a great relief to managers of traditional banks who have come under attack from small entrepreneurial start-up operations in the past. The publicly debated failures of a number of stand-alone and nondominant Internet banking operations over the course of this study have provided further support to our finding. Many high profile financial groups have been obliged to abandon or scale back Internet banking plans. Our findings and qualitative data collected during interviews with retail banking managers indicate the following reasons at the heart of such failures: First, the legacy of bricks \& mortar dominance, i.e., the strength of the physical branch network in the case of retail banking, is a key driver of eventual success with Internet technologies. Contrary to initial managerial perception, the new online components tend to complement the traditional off-line channels. Thus, successful firms tend to embrace both worlds. Second, customer dominance, i.e., the strength of the existing customer base, equally drives longer-term performance. New entrants are forced to create a new customer base from zero whereas incumbents merely have to provide sufficient incentives to induce existing customers' conversion to Internet banking. Third, although marginal transaction costs in Internet banking are low, i.e. about $1 \%$ of full branch costs, the initial fixed investment outlay of setting up

${ }^{25}$ In the case of retail banking, channel ownership rests with banks themselves, i.e. by owning bank branches or ATMs. When banking via the Internet, via a mobile phone or other mobile device, or even via a TV at home, the customer himself has ownership of and control over the channel. This empowerment of the customer is a key success factor in the evolution of remote banking services. 
online banking operations often turned out to be significantly higher than originally expected. Part of the reasons can be found in higher uncertainties due to rapid technological change, security concerns by the public and continuously evolving but competing security standards.

\section{Outlook}

If virtual players are unlikely to displace traditional incumbents, what is the managerial outlook we can offer? It is important to understand that the Internet is well-suited as a marketing channel but not as a primary sales channel. Internet banking offers a gateway to entry (cf. Yip 1982), thus creating an initial customer incentive for subsequent and more lucrative cross-selling opportunities. In the case of banking, for example, a basic current account with Internet banking functionality can eventually lead to sales in other retail banking product categories, such as credit cards, mortgages, insurance, loans, etc. Nevertheless, relationship banking, i.e., the value-adding face-to-face contact between advisor and customer, typically held at a branch office, remains essential to the retail banking model for the time being and is not yet being undermined by the emergence of pure transactional banking on other fronts.

Which of the new channel innovations are likely to prevail? So far, none of the subsequent innovations in post-Internet banking channels have been able to attract sufficient critical mass in customer adoption. Compared to the impressive evolution of Internet banking, they must be considered as failures for the time being. Overall, it remains cloudy which channels will represent the suitable future media for consumer e-commerce: interactive digital television sets, personal computers, or mobile devices (e.g., see Barwise 2001). For example, the emerging third-generation (3G) mobile technology could undermine the personal computer's current dominance as a medium once the new 3G standard has reached critical mass. Yet, video clips, music and gaming are likely to attract more users than banking. The potential success of the home television set as a new medium for personal banking has also been questioned since it has the aura of a "lean-back" medium. The latter is deemed suitable for entertainment purposes but not for "lean-forward" personal banking business ${ }^{26}$. In addition, branch networks (i.e., bricks \& mortar dominance), although still strong in their presence, are likely to decline further in the future due to rising cost pressures in mature and competitive markets. Nonetheless, demand for Internet banking is set to grow further based on demographics and consumers' changing lifestyles which should be manifested over time by increasingly using the online channel in favor of the traditional offline environment.

\footnotetext{
${ }^{26}$ We are grateful for this comment made by the marketing director of a UK stand-alone Internet bank.
} 
Internet banking is now established as an integral component of the retail banking model (pending the next radical innovation perhaps), thus bank managers should now devote more attention to more sophisticated customer relationship management (CRM) tools and further channel integration. This refers to the personalization of banking services with real benefits to customers, for example, in order to simplify their financial lives. Finally, the evolution of electronic finance in industrial countries like Europe and the United States can equally have implications for emerging economies as a development tool (e.g., see Claessens et al. 2001). For countries with underdeveloped financial systems, electronic finance offers an opportunity to leapfrog and overcome a currently poor financial infrastructure. Remote banking solutions that are typically only available to urban customers would be then also become available to small and medium-size firms, farmers, or micro-enterprises. The final impact on emerging economies, however strong in the end, remains to be seen.

\section{Limitations}

Can we generalize our results and apply them to other contexts? Despite the richness of our findings, this paper has a number of limitations as with every piece of research. Our geographic scope is limited to the first countries in Western and Northern Europe who embraced the radical innovation of Internet banking. Moreover, with the empirical context of retail banking we considered only one segment of one particular industry. Nonetheless, our conceptual ideas in the context of radical innovation should be readily transferable to any industry characterized by rapid technological change.

Furthermore, there are trade-offs between qualitative research approaches based on a series of in-depth interviews with managers, for example, and the quantitative hypothesis testing approach we employed. Whenever possible, we aimed to supplement our factual and quantitative data with the richness of qualitative information during selective telephone interviews with managers. This allowed us to better understand the dynamics of the empirical context while still benefiting from the statistical power of our results. Other limitations include using annual accounting data as a proxy for measuring our constructs in some cases, e.g., financial dominance. Such data are subject to a certain variance as a result of different accounting regulations by country and one-off accounting effects which bear in reality no relation to our focal innovation.

Finally, we could encounter a survival bias of firms, as we did not include those firms that had already exited the market before we started the data collection. However, we did include in our study those firms which exited during the investigation horizon. Other response biases may include bank managers supplying potentially erroneous information in isolated 
cases due to lack of memory, fragmented internal company documentation, or wrong communication.

\section{Future Research}

Future research efforts on the theme of radical innovation should apply our conceptual ideas to an extended geographical and industry scope. One particularly interesting geographic region will be Eastern Europe, where most electronic finance innovation has yet to take place. Instead of starting with tabula rasa, any such research initiative would then be able to compare our comprehensive account of radical innovation with any subsequent, possibly even more rapid evolutions thereof. In addition, future research should devote more attention to the analysis of the phenomenon of industry-wide innovation from inception. Likewise, fruitful future research avenues can be found in the broader context of Internet technologies as a radical innovation in order to understand the new phenomenon and its implications better. This study embodies on such account from a backward-looking, historical perspective. Finally, we hope that future research will produce a continuous stream of research on the theme of radical innovation by scrutinizing different aspects thereof. Our exploration and Sorescu et al. (2003) represent merely two examples in this context.

\section{Conclusions}

In this study, we analyzed one aspect of radical innovation that had previously not received sufficient attention in the literature: legacy effects. We hope that some of the remaining gaps could be filled by this study and that we were able to reverse the prevalent pessimistic view of legacies in innovation to some extent. During the course of this research, we derived a number of theoretical hypotheses grouped according to certain aspects of legacy. We then tested these hypotheses by estimating parameters based on a fully specified model explaining speed to radical innovation and market performance simultaneously as dependent variables. Three-stage least squares results performed on three different models yielded significant support for our hypotheses.

One of the main findings of our research is the dual effect of dominance. While slowing down initial speed to radical innovation, dominant firms are ultimately prevailing in the market. In other words, it may not be too harmful to enter the "game" late if firms are able to commit sufficient resources to prevail over competitors in the end. This could be achieved, for example, by entering the market late but with a superior banking platform based on a later and thus more sophisticated technology. As dominance prevails in terms of market performance, we are unable to find any evidence of an "attacker's advantage" (cf. Foster 1986) from small, 
entrepreneurial new entrants vis-à-vis more dominant incumbents. Similarly, our results in the context of European Internet banking suggest that the inherent advantages from being a nondominant first-mover or early-mover are likely to be limited and short-lived.

Furthermore, legacies are not always negative, as we found that experience in previous related technologies can have a positive impact on adopting the focal radical innovation faster. Yet, the negative legacy effect can apply to subsequent market performance in the case of prior technologies that are likely to become obsolete. The organizational dimensions of independence and being a new player both contribute significantly and positively to rapid entry. Finally, we find that country legacies in terms of market and technological infrastructure do matter in the context of radical innovation.

Overall, this study seeks to position itself as a solid empirical contribution within a novel innovation context across borders, Internet banking in Europe, and by complementing earlier qualitative and single-country case studies. 


\section{References}

Abernathy, William J. and Clark, Kim B. (1985), "Mapping the Winds of Creative Destruction", Research Policy, Vol. 14, pp. 3-22.

Anderson, Philip and Tushman, Michael L. (1990), "Technological Discontinuities and Dominant Designs: A Cyclical Model of Technological Change”, Administrative Science Quarterly, Vol. 35, No. 4 (December), pp. 604-33.

Anderson, Wilton Thomas and Challagalla, Goutam N. (1994), "The Negative Legacy of Consumption", International Journal of Research in Marketing, Vol. 11, No. 2 (March), pp. 165-76.

Arrow, Kenneth (1962), "Economic Welfare and the Allocation of Resources for Inventions", in T. Nelson (ed.), The Rate and Direction of Inventive Activity: Economic and Social Factors, Princeton, NJ: Princeton University Press, pp. 609-25.

Bain, Joseph S. (1968), Industrial Organization, 2nd edition, New York, NY; London: John Wiley \& Sons.

Banks, Erik (2001), e-Finance - The Electronic Revolution, Chichester and New York, NY: John Wiley \& Sons, Ltd.

Barwise, Patrick (2001), “TV, PC, or Mobile? Future Media for Consumer e-Commerce”, Business Strategy Review, Vol. 12, No. 1, pp. 35-42.

Bass, Frank M. (1969), “A New Product Growth Model for Consumer Durables”, Management Science, Vol. 15 (January), pp. 215-27.

Bianchi, Alessandro; Caivano, Danilo; Marengo, Vittorio; Visaggio, Giuseppe. (2003) "Iterative Reengineering of Legacy Systems", IEEE Transactions on Software Engineering, Vol. 29, No. 3 (March), pp. 225-41.

Borenstein, Severin (1990), “Airline Mergers, Airport Dominance, and Market Power”, American Economic Review Papers and Proceedings, Vol. 80, No. 2, pp. 400-404.

Borenstein, Severin (1991), “The Dominant-Firm Advantage in Multiproduct Industries: Evidence From the US Airlines", Quarterly Journal of Economics, Vol. 106, No. 4 (November), pp. 1237-66.

Bowman, Douglas and Gatignon, Hubert (1996), "Order of Entry as a Moderator of the Effect of the Marketing Mix on Market Share", Marketing Science, Vol. 15, No. 3 (Summer), pp. 222-42.

Brockner, Joel (1992), “The Escalation of Commitment to a Failing Course of Action: Toward Theoretical Progress", Academy of Management Review, Vol. 17, No. 1 (January), pp. 39-62.

Brooke, Carole and Ramage, Magnus (2001), “Organizational Scenarios and Legacy Systems", International Journal of Information Management, Vol. 21, No. 5 (October), pp. 36584.

Camerer, Colin F. (1988), "Gifts as Economic Signals and Social Symbols”, American Journal of Sociology, Supplement, Vol. 30, pp. S180-S214.

Camerer, Colin F. and Weber, Roberto A. (1999), “The Econometrics and Behavioral Economics of Escalation of Commitment: A Re-Examination of Staw", Journal of Economic Behavior \& Organization, Vol. 39, No. 1 (May), pp. 59-83.

Chaganti, Rajeswararao and Damanpour, Fariborz (1991), "Institutional Ownership, Capital Structure, and Firm Performance", Strategic Management Journal, Vol. 12, No. 7 (October), pp. 479-91. 
Chandrashekaran, Murali; Mehta, Raj; Chandrashekaran, Rajesh; and Grewal, Rajdeep (1999), "Market Motives, Distinctive Capabilities, and Domestic Inertia: A Hybrid Model of Innovation Generation", Journal of Marketing Research, Vol. 36, No. 1 (February), pp. 95-102.

Chandy, Rajesh K. and Tellis, Gerard J. (1998), “Organizing for Radical Product Innovation: The Overlooked Role of Willingness to Cannibalize", Journal of Marketing Research, Vol. 35, No. 4 (November), pp. 474-487.

Chandy, Rajesh K. and Tellis, Gerard J. (2000), “The Incumbent's Curse? Incumbency, Size, and Radical Product Innovation”, Journal of Marketing, Vol. 64, No. 3 (July), pp. 117.

Chandy, Rajesk K.; Prabhu, Jaideep C.; and Antia, Kersi D. (2003), "What Will the Future Bring? Dominance, Technology Expectations, and Radical Innovation", Journal of Marketing, Vol. 66, July.

Choi, Chong-Ju and Kim, Jai-Boem (1996), "Reputation, Learning and Quality Uncertainly”, Journal of Consumer Marketing, Vol. 13, No. 5, pp. 47-56.

Christensen, Clayton M. (1993), “The Rigid Disk Drive Industry: A History of Commercial and Technological Turbulence”, Business History Review, Vol. 67, No. 4 (Winter), pp. 531-88.

Christensen, Clayton M. (1997), The Innovator's Dilemma: When New Technologies Cause Great Firms to Fail, Boston, MA: Harvard Business School Press.

Christensen, Clayton M. and Bower, Joseph L. (1996), "Customer Power, Strategic Investment, and the Failure of Leading Firms", Strategic Management Journal, Vol. 17, No. 3 (March), pp. 197-219.

Claessens, Stijn; Glaessner, Thomas; and Klingebiel, Daniela (2001), "E-Finance in Emerging Markets: Is Leapfrogging Possible?”, Financial Sector Discussion Paper No. 7 (June), Washington, D.C.: The World Bank.

Cohen, Wesley and Levin, Richard C. (1989), "Empirical Studies of Innovation and Market Structure", in: Handbook of Industrial Organization, Vol. 2, Richard Schmalensee and Robert D. Willig (eds.), New York, NY: Elsevier Science Publishers, pp. 1059-1107.

Colarelli O’Connor, Gina (1998), “Market Learning and Radical Innovation: A Cross Case Comparison of Eight Radical Innovation Projects", Journal of Product Innovation Management, Vol. 15, No. 2 (March), pp. 151-66.

Cooper, Arnold C. and Schendel, Dan (1976), "Strategic Responses to Technological Threats", Business Horizons, Vol. 19, No. 1 (February), pp. 61-8.

Dacin, M. Tina; Goodstein, Jerry; and Scott, W. Richard (2002), "Institutional Theory and Institutional Change: Introduction to the Special Research Forum, Academy of Management Journal, Vol. 45, No. 1 (February), pp. 45-57.

Damanpour, Fariborz (1987), “The Adoption of Technological, Administrative, and Ancillary Innovations: Impact of Organizational Factors", Journal of Management, Vol. 13, No. 4 (Winter), pp. 675-88.

Damanpour, Fariborz (1991), "Organizational Innovations: A Meta-Analysis of Effects of Determinants and Moderators", Academy of Management Journal, Vol. 34, No. 3 (September), pp. 555-90.

Damanpour, Fariborz and Gopalakrishnan, Shanthi (2001), "The Dynamics of the Adoption of Product and Process Innovations in Organizations", Journal of Management Studies, Vol. 38, No. 1 (January), pp. 45-65. 
Dekimpe, Marnik G.; Parker, Philip M.; and Sarvary, Miklos (2000), "Global Diffusion of Technological Innovations: A Coupled-Hazard Approach”, Journal of Marketing Research, Vol. 37, No. 1 (February), pp. 47-59.

Deshpandé, Rohit; Farley, John U.; and Webster, Frederick E. (1993), "Corporate Culture, Customer Orientation, and Innovativeness in Japanese Firms: A Quadrad Analysis”, Journal of Marketing, Vol. 57 (January), pp. 23-37.

Dewar, Robert D. and Dutton, Jane E. (1986), "The Adoption of Radical and Incremental Innovations: An Empirical Analysis", Management Science, Vol. 32 No. 11 (November), pp. 1422-33.

Dhebar, Anirudh (1996), "Speeding High-Tech Producer, Meet the Balking Consumer”, Sloan Management Review, Vol. 37, No. 2 (Winter), pp. 37-49.

Foster, Richard N. (1986), Innovation: The Attacker's Advantage, London: Macmillan.

Fuentelsaz, Lucio; Gomez, Jaime; and Polo, Yolanda (2002) “Followers' Entry Timing: Evidence from the Spanish Banking Sector after Deregulation", Strategic Management Journal, Vol. 23, No. 3 (March), pp. 245-264.

Garcia, Rosanna and Calantone, Roger (2002), “A Critical Look at Technological Innovation Typology and Innovativeness Terminology: A Literature Review, Journal of Product Innovation Management, Vol. 19, pp. 110-132.

Gatignon, Hubert; Eliashberg, Jehoshua; and Robertson, Thomas S. (1989), "Modeling Multinational Diffusion Patterns: An Efficient Methodology, Marketing Science, Vol. 8, No. 3 (Summer), pp. 231-47.

Gatignon, Hubert; Tushman, Michael L.; Smith, Wendy; and Anderson, Philip (2002), “A Structural Approach to Assessing Innovation: Construct Development of Innovation Locus, Type, and Characteristics”, Management Science, Vol. 48, No. 9 (September), pp. 1103-22.

Ghemawat, Pankaj (1991), "Market Incumbency and Technological Inertia”, Marketing Science, Vol. 10, No. 2 (Spring), pp. 161-171.

Golder, Peter N. and Gerard J. Tellis (1993), "Pioneer Advantage: Marketing Logic or Marketing Legend?” Journal of Marketing Research, Vol. 30 (May), pp. 158-170.

Golder, Peter N. and Gerard J. Tellis (1997), "Will it Ever Fly? Modeling the Takeoff of Really New Consumer Durables”, Marketing Science, Vol. 16, No. 3, pp. 256-70.

Gopalakrishnan, Shanthi (2000), "Unravelling the Links between Dimensions of Innovation and Organizational Performance", Journal of High Technology Management Research, Vol. 11, No. 1 (Spring), pp. 137-153.

Gopalakrishnan, Shanthi and Bierly, Paul (1997), "Organizational Innovation and Strategic Choices: A Knowledge-Based View”, Academy of Management Proceedings, pp. 422-6.

Green, Stephen G. and Gavin, Mark B. (1995), "Assessing a multidimensional measure of radical technological innovation, IEEE Transactions on Engineering Management, Vol. 42, No. 3 (August), pp. 203-14.

Greene, William H. (2003), Econometric Analysis, 5th edition, New York: Prentice Hall (Pearson Education International).

Grewal, Rajdeep and Dharwadkar, Ravi (2002), “The Role of the Institutional Environment in Marketing Channels”, Journal of Marketing, Vol. 66, No. 3 (July), pp. 82-97.

Han, Jin K., Kim, Manwoon; and Srivastava, Rajendra K. (1998), “Market Orientation and Organizational Performance: Is Innovation the Missing Link?” Journal of Marketing, Vol. 62, No. 4 (October), pp. 30-45. 
Hannan, Timothy H. and John M. McDowell (1984), "The Determinants of Technology Adoption: the Case of the Banking Firm", Rand Journal of Economics, Vol. 15, No. 3, pp. 328-335

Hannan, Timothy H. and John M. McDowell (1986), "Rival Precedence and the Dynamics of Technology Adoption: an Empirical Analysis”, Economica, Vol. 54, pp. 155-171.

Hannan, Timothy H. and John M. McDowell (1990), "The Impact of Technology Adoption on Market Structure", The Review of Economics and Statistics, Vol. 72, No. 1, pp. 164-168.

Henderson, Rebecca (1993), "Underinvestment and Incompetence as Responses to Radical Innovation: Evidence from the Photolithographic Alignment Equipment Industry", RAND Journal of Economics, Vol. 24, No. 2 (Summer), pp. 248-70.

Henderson, Rebecca M. and Clark, Kim B. (1990), “Architectural Innovation: The Reconfiguration of Existing Product Technologies and the Failure of Established Firms”, Administrative Science Quarterly, Vol. 35, No. 1 (March), pp. 9-30.

Hill, Charles W. L. and Rothaermel, Frank T. (2003), “The Performance of Incumbent Firms in the Face of Radical Technological Innovation", Academy of Management Review, Vol. 28, No. 2 (April), pp. 257-74.

Hitt, Lorin M. and Frei, Frances X. (2002), “Do Better Customers Utilize Electronic Distribution Channels? The Case of PC Banking", Management Science, Vol. 48, No. 6 (June), pp. 732-48.

Hofstede, Geert (1990), Culture's Consequences, 2nd edition, Beverly Hills, CA: Sage.

Isobe, Takehiko; Makino, Shige; and Montgomery, David B. (2000), "Resource Commitment, Entry Timing, and Market Performance of Foreign Direct Investments in Emerging Economies: The Case of Japanese International Joint Ventures in China", Academy of Management Journal, Vol. 43, No. 3 (June), pp. 468-85.

Kalakota, Ravi and Frei, Frances X. (1997), "Frontiers of On-Line Financial Services” in Cronin, Mary J. (ed.), Banking and Finance on the Internet, London and New York, NY: Van Nostrand Reinhold, pp. 19-58.

Kalyanaram, Gurumurthy; Robinson, William T.; and Urban, Glen L. (1995), “Order of Market Entry: Established Empirical Generalizations, Emerging Empirical Generalizations, and Future Research”, Marketing Science, Vol. 14, No. 3, pp. 212-21.

Kerin, R. A., P. R. Varadarajan, et al. (1992), "First-Mover Advantage: A Synthesis, Conceptual Framework, and Research Propositions." Journal of Marketing, Vol. 56 (October), pp. 33-52.

Kessler, Eric H. and Chakrabarti, Alok K. (1999), "Speeding up the Pace of New Product Development", Journal of Product Innovation Management, Vol. 16, No. 2 (March), pp. 231-47.

King, Andrew A. and Tucci, Christopher L. (2000), "Responding to Technology-Created Market Niches: Do Industry-Specialized Capabilities Facilitate or Hamper Entry?” Academy of Management Proceedings 2000, pp. 1-6.

King, Andrew A. and Tucci, Christopher L. (2002), "Incumbent Entry into New Market Niches: The Role of Experience and Managerial Choice in the Creation of Dynamic Capabilities", Management Science, Vol. 48, No. 2 (February), pp. 171-86.

Kochhar, Rahul and David, Parthiban (1996), "Institutional Investors and Firm Innovations: A Test of Competing Hypotheses”, Strategic Management Journal, Vol. 17, No. 1 (January), pp. 73-84. 
Kumar, V.; Ganesh, Jaishankar; and Echambadi, Raj (1998), "Cross-National Diffusion Research: What Do We Know and How Certain Are We?", Journal of Product Innovation Management, Vol. 15, No. 3 (May), pp. 255-68.

Leifer, Richard; McDermott, Christopher M.; Colarelli O’Connor, Gina et al. (2000), Radical Innovation, Boston, MA: Harvard Business School Press.

Lieberman, Marvin B. and David B. Montgomery (1998) "First-Mover (Dis)Advantages: Retrospective and Link with the Resource-Based View" Strategic Management Journal, Vol. 19, No. 12 (December), pp. 1111-1125.

Lieberman, Marvin. B. and David B. Montgomery (1988), "First-Mover Advantages" Strategic Management Journal, Vol. 9 (Special Issue), pp. 41-58.

Lilien, Gary L. and Yoon, Eunsang (1990), "The Timing of Competitive Market Entry: An Exploratory Study of New Industrial Products", Management Science, Vol. 36, No. 5 (May), pp. 568-85.

Mahajan, Vijay and Muller, Eitan (1994), "Innovation Diffusion in a Borderless Global Market: Will the 1992 Unification of the European Community Accelerate Diffusion of New Ideas, Products and Technologies?", Technological Forecasting and Social Change, Vol. 45 (March), pp. 221-37.

McDermott, Christopher M. and Colarelli O’Connor, Gina (2002), “Managing Radical Innovation: An Overview of Emergent Strategy Issues", Journal of Product Innovation Management, Vol. 19, No. 6 (November), pp. 424-38.

Munir, Kamal A. and Phillips, Nelson (2002), "The Concept of Industry and the Case of Radical Technological Change", Journal of High Technology Management Research, Vol. 13, No. 2 (Autumn), pp. 279-97.

Nelson, Richard R. and Winter, Sidney G. (1982), An Evolutionary Theory of Economic Change, Cambridge, MA: Belknap Press

Pavitt, K.; Robson, M.; and Townsend, J. (1987), “The Size Distribution of Innovating Firms in the UK: 1945-1983”, Journal of Industrial Economics, Vol. 35 (March), pp. 297316.

Pistorius, Carl W. I. and Utterback, James M. (1997), "Multi-Mode Interaction among Technologies”, Research Policy, Vol. 26, No. 1 (March), pp. 67-84.

Pleatsikas, Christopher and Teece, David (2001), "The Analysis of Market Definition and Market Power in the Context of Rapid Innovation”, International Journal of Industrial Organization, Vol. 19, No. 5, pp. 665-93.

Roberts, Peter W. and Amit, Raphael (2003), “The Dynamics of Innovative Activity and Competitive Advantage: The Case of Australian Retail Banking, 1981 to 1995", Organization Science, Vol. 14, No. 2 (March/April), pp. 107-22.

Robinson, William T., G. Kalyanaram, et al. (1994). "First-Mover Advantages from Pioneering New Markets: A Survey of Empirical Evidence", Review of Industrial Organization Vol. 9, No. 1, pp. 1-23.

Rogers, Everett M. (1995), Diffusion of Innovations, 4th edition, New York, NY: The Free Press.

Rothaermel, Frank T. (2001a), “Incumbent's Advantage Through Exploiting Complementary Assets Via Interfirm Cooperation”, Strategic Management Journal, Vol. 22, No. 6/7 (June/July), pp. 687-99. 
Rothaermel, Frank T. (2001b), “Complementary Assets, Strategic Alliances, and the Incumbent's Advantage: An Empirical Study of Industry and Firm Effects in the Biopharmaceutical Industry”, Research Policy, Vol. 30, No. 8 (October), pp. 1235-50.

Saloner, Garth and Shepard, Andrea (1995), “Adoption of Technologies with Network Effects: An Empirical Examination of the Adoption of Automated Teller Machines", RAND Journal of Economics, Vol. 26, No. 3 (Autumn), pp. 479-501.

Schelling, Thomas C. (1960), The Strategy of Conflict, Cambridge, MA: Harvard University Press.

Scherer, Frederic M. (1980), Industrial Market Structure and Economic Performance, Chicago: Rand McNally.

Schmidt, Jeffrey B. and Calantone, Roger J. (2002), "Escalation of Commitment During New Product Development", Journal of the Academy of Marketing Science, Vol. 30 No. 2 (Spring), pp. 103-18.

Schneidewind, Norman F. and Ebert, Christof (1998), "Preserve or Redesign Legacy Systems?" IEEE Software, Vol. 15, No. 4 (July/August), pp. 14-17.

Schoenecker, Timothy S. and Cooper, Arnold C. (1998), "The Role of Firm Resources and Organizational Attributes in Determining Entry Timing: A Cross Industry Study”, Strategic Management Journal, Vol. 19, No. 12, pp. 1127-1143.

Schumpeter, Joseph A. (1934), The Theory of Economic Development, Cambridge, MA: Harvard University Press (first published 1912 in German).

Schumpeter, Joseph A. (1950), Capitalism, Socialism, and Democracy, 3rd edition, New York, NY: Harper Brothers.

Serrano, Miguel A.; Carver, Doris L.; and Montes de Oca, Carlos (2002), "Reengineering Legacy Systems for Distributed Environments", Journal of Systems \& Software, Vol. 64, No. 1 (October), pp. 37-55.

Shamsie, Jamal (2003), “The Context of Dominance: An Industry-Driven Framework for Exploiting Reputation”, Strategic Management Journal, Vol. 24, No. 3 (March), pp. 199-215.

Sorescu, Alina; Chandy, Rajesk K.; and Prabhu, Jaideep C. (2003), "Sources and Financial Consequences of Radical Innovation: Insights from Pharmaceuticals", Journal of Marketing, Vol. 66, October, pp. 82-102.

Staw, Barry M. (1981), “The Escalation of Commitment To a Course of Action”, Academy of Management Review, Vol. 6, No. 4 (October), pp. 569-76.

Szymanski, David M. and Bharadwaj, Sundar G. (1993), "An Analysis of the Market ShareProfitability Relationship”, Journal of Marketing, Vol. 57, No. 3 (July), pp. 1-18.

Szymanski, David M. and Troy, Lisa C. (1995), "Order of Entry and Business Performance: An Empirical Synthesis and Reexamination”, Journal of Marketing, Vol. 59, No. 4 (October), pp. 17-33.

Teece, David J. (1986), "Profiting from technological innovation: implications for integration, collaboration, licensing and public policy", Research Policy, Vol. 15, pp. 285-305.

Tellis, Gerard J.; Stremersch, Stefan; and Yin, Eden (2003), “The International Takeoff of New Products: The Role of Economics, Culture and Country Innovativeness", Marketing Science, Vol. 22, No. 2, pp. 188-208.

Tripsas, Mary (1997), "Unraveling the Process of Creative Destruction: Complementary Assets and Incumbent Survival in the Typesetter Industry", Strategic Management Journal, Vol. 18, No. 6 (Summer Special Issue), pp. 119-142. 
Tripsas, Mary and Gavetti, Giovanni (2000), "Capabilities, Cognition, and Inertia: Evidence from Digital Imaging”, Strategic Management Journal, Vol. 21, No. 10/11 (October/November), pp. 1147-61.

Tushman, Michael L. and Anderson, Philip (1986), “Technological Discontinuities and Organizational Environments”, Administrative Science Quarterly, Vol. 31, No. 3 (September), pp. 439-65.

Utterback, James M. (1994), Mastering the Dynamics of Innovation, Boston, MA: Harvard Business School Press.

Wood, Douglas (2002), “An Historical Appraisal of Information Technology in Commercial Banking”, Electronic Markets, Vol. 12, No. 3 (September), pp. 192-205.

Yip, George S. (1982), Gateways to Entry: A Corporate-Strategy Perspective, Lexington, MA: Lexington Books.

Zander, Ivo and Sölvell, Örjan (2000), "Cross-Border Innovation in the Multinational Corporation", International Studies of Management and Organisation, Vol. 30, No. 2 (Summer), pp. 44-67.

Zellner, Arnold and Theil, Henri (1962), “Three-Stage Least Squares: Simultaneous Estimation of Simultaneous Equations”, Econometrica, Vol. 30, No. 1 (January) pp. 63-68. 




\section{ESMT Working Papers}

\begin{tabular}{|c|c|c|}
\hline & $\begin{array}{l}\text { ESMT } \\
\text { No. }\end{array}$ & $\begin{array}{l}\text { Competence } \\
\text { Center }\end{array}$ \\
\hline $\begin{array}{l}\text { Legacy Effects in Radical Innovation: A Study of European } \\
\text { Internet Banking }\end{array}$ & 08-002 & $\begin{array}{l}\text { Management } \\
\text { and }\end{array}$ \\
\hline $\begin{array}{l}\text { Erik H. Schlie, ESMT } \\
\text { Jaideep C. Prabhu, Tanaka Business School, Imperial College } \\
\quad \text { London } \\
\text { Rajesh K. Chandy, Carlson School of Management, University } \\
\quad \text { of Minnesota }\end{array}$ & & Technology \\
\hline $\begin{array}{l}\text { Upsetting Events and Career Investments in the Russian } \\
\text { Context }\end{array}$ & 08-001 & Leadership \\
\hline $\begin{array}{l}\text { Konstantin Korotov, ESMT } \\
\text { Svetlana Khapova, ESMT Visiting Professor and Assistant } \\
\text { Professor at VU University Amsterdam }\end{array}$ & & \\
\hline $\begin{array}{l}\text { Ambiguity Aversion and the Power of Established Brands } \\
\text { A. V. Muthukrishnan, Hong Kong University of Science and } \\
\text { Technology } \\
\text { Luc Wathieu, ESMT }\end{array}$ & 07-005 & $\begin{array}{l}\text { Management } \\
\text { and } \\
\text { Technology }\end{array}$ \\
\hline $\begin{array}{l}\text { Accelerated Development of Organizational Talent } \\
\text { Konstantin Korotov, ESMT }\end{array}$ & 07-004 & Leadership \\
\hline $\begin{array}{l}\text { Usage and Diffusion of Cellular Telephony, 1998-2004 } \\
\text { Michat Grajek, ESMT } \\
\text { Tobias Kretschmer, Ludwig-Maximilians-Universität München }\end{array}$ & 07-003 & $\begin{array}{l}\text { European } \\
\text { Competitiveness }\end{array}$ \\
\hline $\begin{array}{l}\text { Estimating Level Effects in Diffusion of a New Technology: } \\
\text { Barcode Scanning at the Checkout Counter }\end{array}$ & 07-002 & $\begin{array}{l}\text { European } \\
\text { Competitiveness }\end{array}$ \\
\hline $\begin{array}{l}\text { Jonathan Beck, Humboldt Universität zu Berlin } \\
\text { Michat Grajek, ESMT } \\
\text { Christian Wey, Technische Universität, Berlin }\end{array}$ & & \\
\hline $\begin{array}{l}\text { Estimating Network Effects and Compatibility in Mobile } \\
\text { Telecommunication }\end{array}$ & 07-001 & $\begin{array}{l}\text { European } \\
\text { Competitiveness }\end{array}$ \\
\hline
\end{tabular}

Michał Grajek, ESMT 


\section{ESMT}

European School of Management and Technology $\mathrm{GmbH}$

ESMT Campus

Schlossplatz 1

10178 Berlin

Phone: +49(0)30212 31-1279

www.esmt.org 